\title{
$\mathrm{UiO}$ : Det juridiske fakultet
}

\section{Elektronisk kommunikasjon i aksjeselskapsforhold}

med særlig fokus på kravet om at kommunikasjonen må foregå på en betryggende måte

Kandidatnummer: 559

Leveringsfrist: 25.11 .2019

Antall ord: 16061 


\section{Innholdsfortegnelse}

1 INNLEDNING. 1

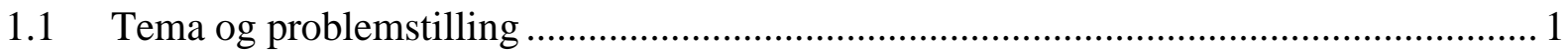

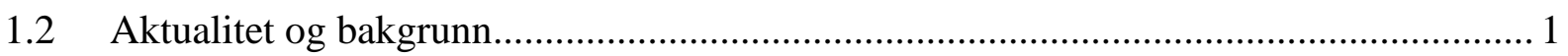

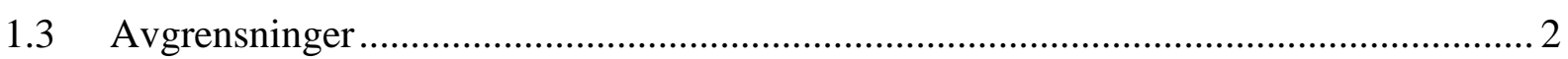

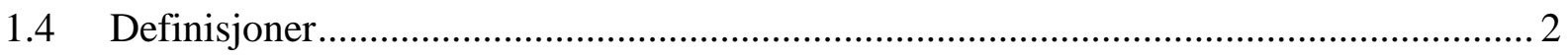

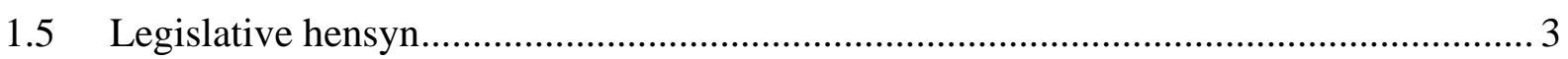

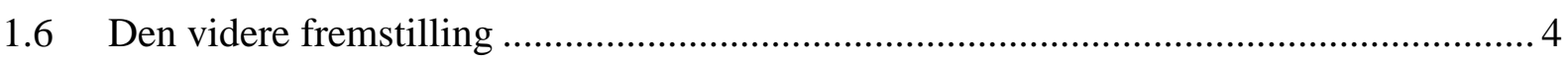

2 OVERORDNET OM KRAVET TIL BETRYGGENDE MÅTE ..............................5

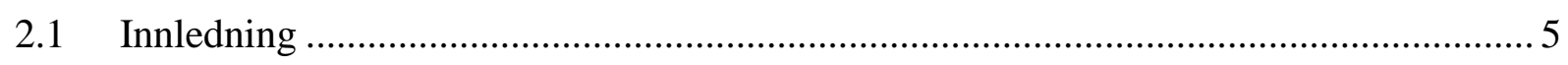

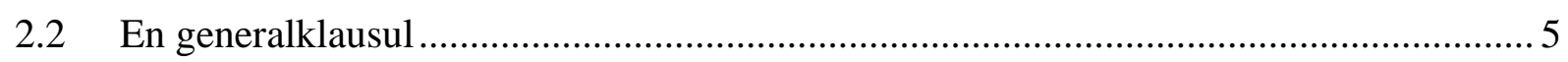

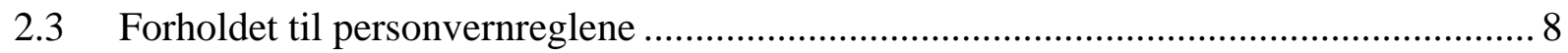

3 KOMMUNIKASJON FRA SELSKAPET TIL AKSJON ERENE .........................9

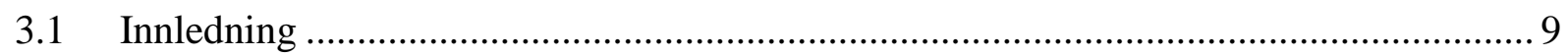

3.2 Selskapets meldinger mv. til aksjonærene skal gis på den måten styret bestemmer ....... 9

3.3 Krav om betryggende og hensiktsmessig kommunikasjonsmåte ................................. 14

3.4 Selskapets aktivitetsplikt hvor elektronisk kommunikasjon ikke kan gjennomføres som fastsatt av styret.

3.5 Styret skal informere aksjonærene i rimelig tid før ny kommunikasjonsmåte tas i bruk

4 KOMMUNIKASJON FRA AKSJON ERENE TIL SELSKAPET ...................... 19

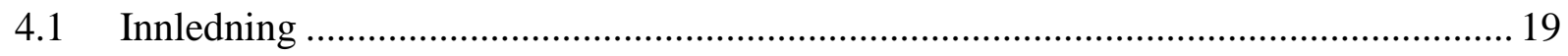

4.2 Aksjonærene kan alltid kommunisere til selskapets oppgitte digitale adresse ............. 19

4.3 Elektroniske meldinger mv. som ikke sendes til selskapets oppgitte digitale adresse .. 20

4.4 Elektroniske meldinger mv. sendt av andre enn aksjonæren selv............................... 21

5 BRUK AV ELEKTRONISKE HJELPEMIDLER PÅ

GENERALFORSAMLINGEN............................................................................ 23

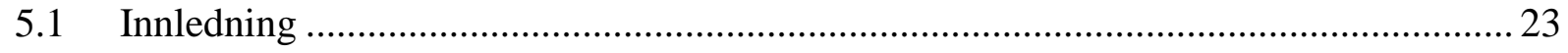

5.2 Forenklet generalforsamling som gjennomføres utelukkende ved hjelp av elektroniske

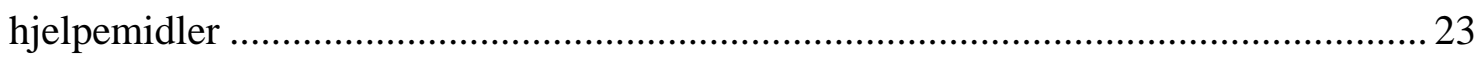

5.2.1 Krav om at ingen aksjonærer motsetter seg forenklet behandling .................. 23

5.2.2 Krav om betryggende gjennomføringsmåte? ............................................... 24 
5.3 Ordinær generalforsamling som gjennomføres fysisk, men hvor én eller flere deltar

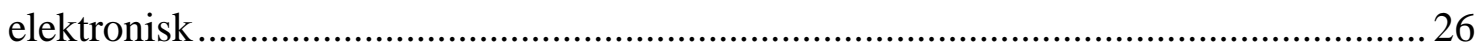

5.3.1 Krav om betryggende måte å kontrollere deltakelse og stemmegivning.......... 26

5.3.2 Styrets rett til å nekte elektronisk deltakelse ved saklig grunn........................ 28

5.3.3 Domstolenes adgang til å prøve styrets saklighetsskjønn .............................. 30

5.3.4 Betryggende metode å autentisere avsenderen av forhåndsstemme................. 30

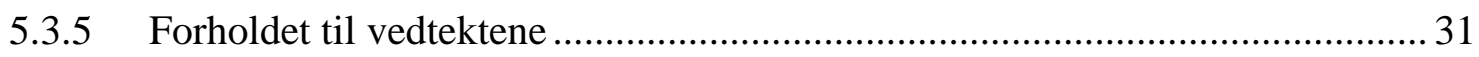

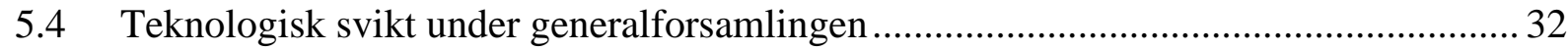

6 BRUK AV ELEKTRONISKE HJELPEMIDLER I STYRET ............................. 34

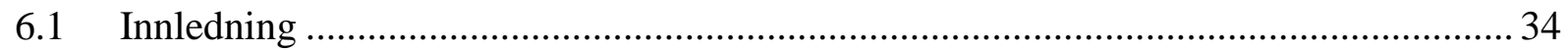

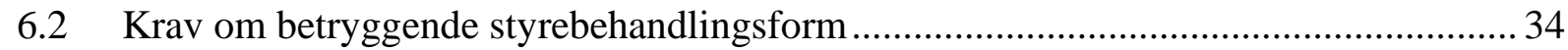

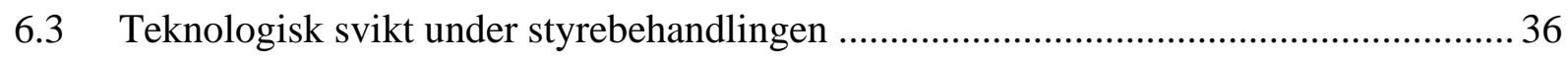

7 OPPBEVARING AV OG INNSYN I SELSKAPSDOKUMENTASJON............... 38

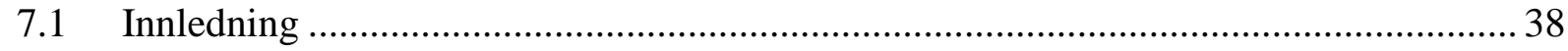

7.2 Dokumentasjon som kreves utarbeidet etter aksjeloven ........................................... 38

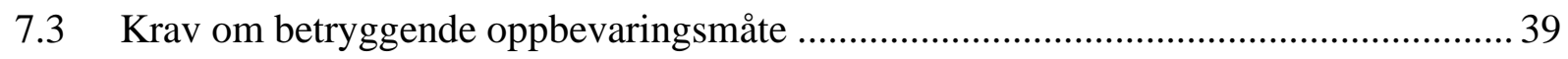

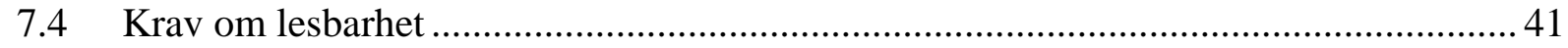

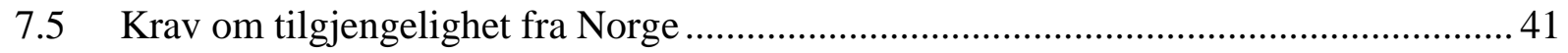

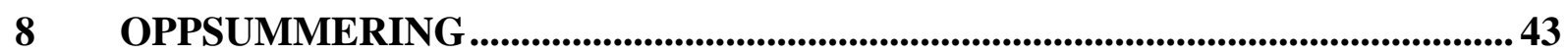

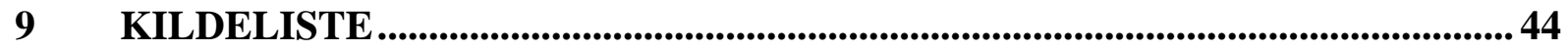

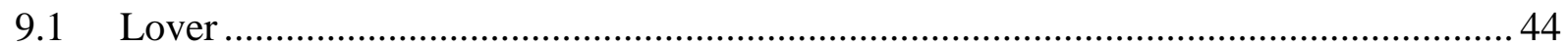

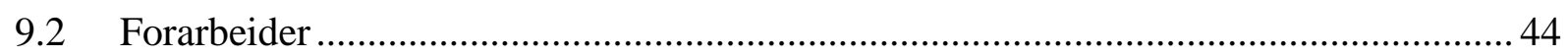

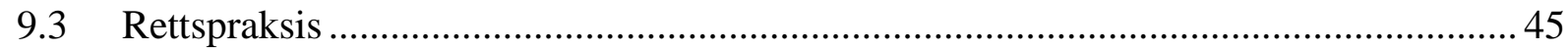

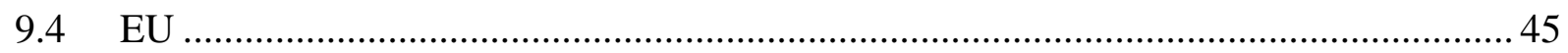

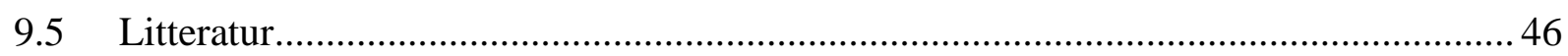




\section{Innledning}

\section{$1.1 \quad$ Tema og problemstilling}

Kommunikasjon innad i aksjeselskapet og overfor aksjonærene er en grunnleggende forutsetning for å drifte selskapet mest mulig effektivt. Norsk selskapsrett har tradisjonelt bygget på fysisk kommunikasjon, typisk i form av utveksling av papirdokumenter og fysiske møter. Den digitale samfunnsutviklingen har imidlertid åpnet dørene for kommunikasjon ved bruk av elektroniske løsninger. I dag er derfor elektronisk kommunikasjon (heretter forenklet «ekommunikasjon») sidestilt med tradisjonell kommunikasjon, jf. lov 13. juni 1997 om aksjeselskaper (heretter «aksjeloven» og «asl.») § 1-6 (2).

Ekommunikasjon brukes i flere aksjeselskapsrettslige sammenhenger og relasjoner som oppgaven vil ta for seg, herunder mellom selskapet og aksjonærene, ved gjennomføring av generalforsamling, av styremøter og ved innsyn i oppbevarte selskapsdokumenter. Videre er ekommunikasjon i stadig utvikling og reiser dermed også flere nye utfordringer. For å imøtekomme dagens og fremtidige utfordringer, med hensyn til risiko for misbruk, feil og systembrudd, stiller aksjeloven krav om at ekommunikasjon må foregå på en «betryggende måte», jf. blant annet $\S \S 1-7$ (1) siste punktum, 5-11 b (1) andre punktum og 6-19 (1).

Oppgaven skal gi en redegjørelse for reglene om bruk av ekommunikasjon i aksjeselskapsforhold, med særlig fokus på hva som i aksjeloven menes med at det må foregå på en «betryggende måte» og hvordan dette kravet er å forstå i de ulike relasjonene. Spørsmålet vil besvares gjennom drøftelser av problemstillinger som aksjelovens regler om ekommunikasjon reiser. Hva må for eksempel selskapet gjøre om en melding til aksjonærens oppgitte e-postadresse aldri kommer til vedkommendes kunnskap fordi denne ikke lenger er i bruk? Hvilke plikter oppstår under generalforsamlingen eller i styret hvor en aksjonær eller et styremedlem som deltar elektronisk, opplever teknologisk svikt og derfor ikke får delta, uttale seg eller avlevere stemme? Har selskapet en plikt til å sørge for at elektronisk oppbevarte selskapsdokumenter som det kan kreves innsyn i, skal sikkerhetskopieres i tilfelle originalfilen skulle bli urettmessig fjernet, $\varnothing$ delagt eller redigert?

\section{$1.2 \quad$ Aktualitet og bakgrunn}

Temaet for oppgaven er aktuelt i lys av den raske elektroniske utviklingen. Dette igangsatte eRegelprosjektet i 1999, som hadde som målsetting «å fjerne unødige rettslige hindringer for elektronisk kommunikasjon» 1 i lovgivningen. Eksempelvis forelå det lenge en hindring i form av at aksjonærene måtte samtykke til bruken av ekommunikasjon i aksjeselskapsforhold, jf.

\footnotetext{
${ }^{1}$ Ot.prp. nr. 108 (2000-2001) s. 11 (punkt 1 Hovedinnholdet i forslaget).
} 
aksjelovens tidligere $\S 18-5$ (1). Som ledd i moderniserings- og forenklingsprosessen av aksjeloven ble dette opphevet ved lov 16. juni 2017 nr. 71 om endringer i aksjelovgivningen mv. (modernisering og forenkling). At den raske teknologiske utviklingen påvirker måter å kommunisere på i selskapet og overfor aksjonærene er også erkjent i EU gjennom digitaliseringsrapporten $^{2}$ fra 2016. I tillegg har reglene om ekommunikasjon ikke vært oppe for domstolene og rettspraksis er derfor fraværende på området. Behovet for rettslig avklaring av oppgavens tema er dermed tilstede på både nasjonalt og internasjonalt nivå. Dette, sammenholdt med at «det meste av kommunikasjonen i næringslivet ... [foregår] elektronisk» ${ }^{3}$, er bakgrunnen for valget av emnet.

\subsection{Avgrensninger}

Aksjelovens regler om ekommunikasjon med andre private rettssubjekter enn aktørene innad i selskapet og overfor selskapet og aksjonærene, som granskere, revisorer og ansatte, faller utenfor oppgavens rammer og vil ikke drøftes. Samme gjelder overfor offentlige myndigheter som Finanstilsynet og Foretaksregisteret. Det avgrenses også mot tilsvarende regler i lov 13. juni 1997 nr. 45 om allmennaksjeselskaper («allmennaksjeloven»). Forskjeller som følger av allmennaksjeloven, vil likevel trekkes frem hvor dette er relevant for å belyse oppgavens tema. Videre er det en egen lov om elektronisk kommunikasjon, lov 4. august 2003 nr. 83 («ekomloven»). Oppgaven skal ikke gi en redegjørelse av reglene som følger av denne loven. Det er heller ingen henvisninger i lovteksten eller forarbeidene som gjør bestemmelsene i ekomloven relevante for aksjeloven.

\subsection{Definisjoner}

Oppgaven fordrer en forståelse av hva som menes med «kommunikasjon», «elektronisk kommunikasjon», «elektroniske løsninger» og «elektroniske hjelpemidler». I tillegg vil det være hensiktsmessig å forklare forskjellen på «synkron»og «asynkron» kommunikasjon.

Begrepet «kommunikasjon» finnes i aksjeloven $§ 5-11$ b (2) første punktum om bruken av elektroniske hjelpemidler under ordinær generalforsamling. Etter ordlyden er det naturlig å definere «kommunikasjon» som formidling av enhver form for informasjon fra et subjekt (avsender) som kommer til kunnskap hos et annet (mottaker). At enhver form for informasjonsutveksling omfattes kommer videre frem av aksjelovens kontekst, som taler om «meldinger $m v$.» (kursivert her), jf. §§ 1-6 (2) og 1-7. I forarbeidene er blant annet varsler og underretninger angitt som ytterligere eksempler på former for kommunikasjon. ${ }^{4}$

\footnotetext{
${ }^{2}$ Report on digitalisation in company law (2016) [https://ec.europa.eu/info/sites/info/files/icleg-report-on-digitalisation-24-march-2016_en.pdf] hentet 18.10.2019.

${ }^{3}$ Prop. 112 L (2016-2017) s. 37 (punkt 4.3.5.1 Regulering av kommunikasjonsmåte).

${ }^{4}$ ibid. s. 103 (punkt 10.1 Til $\S 1-7$ ).
} 
I aksjeloven § 5-11 b (2) første punktum finner man videre igjen begrepet «elektronisk kommunikasjon». Etter vanlig språkforståelse kan «elektronisk kommunikasjon» defineres som en informasjonsformidlingsprosess der budskapet kommuniseres ved hjelp av maskin- og programvareløsninger. Begrepene «elektroniske løsninger» og «hjelpemidler», i blant annet $\S \S 1$ 6 (2) og 5-11 b, er naturlig å forstå som maskin- og programvareløsninger som muliggjør denne kommunikasjonsprosessen.

I et elektronisk perspektiv kan informasjonsutveksling forekomme på en av to måter: synkront eller asynkront. Synkron kommunikasjon foreligger der mottaker får kunnskap om budskapet tilnærmet samtidig med at informasjonen sendes fra avsender. Dette vil ofte være tilfelle ved bruken av direktemeldinger (instant messaging), videokonferanser og nettmøter.

Asynkron kommunikasjon, på den annen side, er der det går en viss tid før budskapet kommer til mottakerens kunnskap. Som eksempel vil dette ofte være tilfelle ved kommunikasjon gjennom e-post. En annen informasjonsutvekslingsform som normalt anses å være asynkron, er proaktiv kommunikasjon. Dette foreligger der avsender gjør informasjon tilgjengelig uten at den sendes direkte til mottaker. Eksempler på proaktiv kommunikasjon kan være publiseringer på firmaets intranett og å gjøre oppbevarte dokumenter tilgjengelig ved innsynsforespørsel.

\subsection{Legislative hensyn}

Oppgaven fordrer videre kjennskap til de legislative hensyn som ligger bak reglene om ekommunikasjon. En grundig behandling av dette er gjengitt i lovproposisjonen utgitt av Næringsog fiskeridepartementet i forbindelse med aksjelovsrevisjonen i 2017, Prop. 112 L (2016-2017) (heretter forkortet «Proposisjonen») punkt 1.1 om bakgrunn og overordnede hensyn. Blant annet begrunnes endringene med et $\emptyset$ nske om en mer effektiv form for kommunikasjon, noe som er ment å skulle gi selskapet bedre anledning til å fokusere på sin kjerneaktivitet. Videre skal ekommunikasjonsreglene fremme samfunnsmessige interesser, som blant annet hensynet til miljø og kostnadsbesparelser for næringslivet.

Ved utformingen av de nye og reviderte reglene var det viktig at styret og aksjonærenes rettigheter og plikter i selskapet ble ivaretatt på en trygg og effektiv måte. Elektroniske kommunikasjonsformer bringer med seg nye utfordringer som risikoen for dataidentitetskrenkelser og andre former for datamanipulasjon. Reglene er derfor utformet på en måte som skal kunne minimere slike risikoelementer, mens de samtidig er gjort teknologin øytrale for å imøtekomme bruken av nye kommunikasjonsløsninger. 
Videre var hensynet til tilgjengelighet og forutberegnelighet for aksjelovens brukere fremtredende under revisjonen. Det var en sentral målsetning å skape et lovverk som «kunne leses og forstås av bedriftene og aksjeeierne selv» ${ }^{5}$. Også selskaper med begrenset juridisk kompetanse skal selv kunne ta i bruk ekommunikasjon i virksomheten etter ønske og behov.

Reglene for bruken av ekommunikasjon i aksjeselskapsforhold kan med det sies å bygge på fire grunnleggende hensyn: 1) forutberegnelighet, 2) behovet for en effektiv og fleksibel drift, 3) behovet for dataintegritet og autentisering og 4) forsvarlig utøvelse av aksjonærenes og styremedlemmenes rettigheter og plikter. Disse vil stå sentralt ved tolkningen av reglene i aksjeloven om ekommunikasjon.

\subsection{Den videre fremstilling}

I kapittel 2 vil noen mer generelle spørsmål som oppstår i forbindelse med kravet til at ekommunikasjon skal foregå på en «betryggende måte», behandles. Videre vil mer konkrete problemstillinger om temaet drøftes løpende. Dette gjøres ved behandlingen av enkelte typesituasjoner der ekommunikasjon anvendes, nærmere bestemt meldinger mv. fra selskapet til aksjonærene (kap. 3) og omvendt (kap. 4), på generalforsamling (kap. 5), i styret (kap. 6) og ved oppbevaring av og innsyn i selskapsdokumentasjon (kap. 7). Avslutningsvis gis en kort oppsummering med henblikk på å besvare oppgavens hovedspørsmål (kap. 8).

\footnotetext{
${ }^{5}$ Prop. 112 L (2016-2017) s. 6 (punkt 1.1 Bakgrunn og overordnede hensyn).
} 


\section{Overordnet om kravet til betryggende måte}

\subsection{Innledning}

I inneværende kapittel vil det gis en presentasjon av kravet til at ekommunikasjon må foregå på en «betryggende måte». Det vil først gis en redegjørelse av begrepets generelle og skjønnsmessige karakter (punkt 2.2) og deretter for regelens forhold til personvernreglene (punkt 2.3).

\subsection{En generalklausul}

Aksjelovens krav til sikker og effektiv kommunikasjon er gjennomgående formulert som et krav til at informasjonsformidlingen skal foregå på en «betryggende måte». Den valgte formuleringen gir angivelser på det som ofte omtales som en generalklausul, en skjønnsmessig regel som åpner for konkrete vurderinger tilpasset ulike situasjoner. Ordlydens teknologinøytrale formulering er godt egnet til å fange opp nye former for kommunikasjon i tråd med den teknologiske utviklingen. Bestemmelsen er derfor velrustet for håndtering av de utfordringer som kan oppstå i fremtiden, men som vanskelig kunne forutses på lovgivningstidspunktet. Dette er en viktig egenskap for å kunne sikre mot uønskede «hull» i lovgivningen ved reguleringen av et område som til hyppighet er gjenstand for nyvinninger. Det er en stor variasjon i bruken av elektroniske løsninger fra selskap til selskap, noe som innebærer et vidt spekter av utfordringer.

Spørsmålet er hva som nærmere inngår i den konkrete og skjønnsmessige vurderingen av om kommunikasjonsmåten har vært «betryggende». En naturlig forståelse av ordlyden tilsier at det gjelder et visst krav med hensyn til sikkerhet for at budskapets opprinnelige innhold kommer til, og bare til, den berettigede mottakers kunnskap. Dette har st $\varnothing t t e$ i forarbeidene til lov 13. mai $1988 \mathrm{nr}$. 26 om inkassovirksomhet og annen inndriving av forfalte pengekrav («inkassoloven») § 3 a om ekommunikasjon. Der fremgår det at «betryggende måte» krever at meddelelsen «må være sendt på en måte som gir tilstrekkelig sikkerhet for at varselet kan komme frem til skyldneren og komme til skyldnerens kunnskap» ${ }^{6}$. Som del av eRegelprosjektet har dette relevans også for aksjeloven, ettersom det skal være «god sammenheng og konsistens mellom selskapslovgivningen og annet regelverk» ${ }^{7}$ når det gjelder tilpasninger til den teknologiske utviklingen.

Ordlyden må imidlertid ses i sammenheng med at det er styret som etter aksjeloven § 1-7 (1) første punktum «bestemmer» hvordan og på hvilken måte kommunikasjonen skal foregå i selskapet. Dette er av hensyn til styret som står «nærmest til å vurdere hvilken kommunikasjonsmåte som er mest hensiktsmessig» ${ }^{8}$ for å oppnå en mest mulig effektiv drift. Ser man derfor

\footnotetext{
${ }^{6}$ Prop. 6 L (2016-2017) s. 47 (punkt 9.3 Til $§ 3$ a).

${ }^{7}$ Prop. 112 L (2016-2017) s. 9 (punkt 2.1 Utredningsoppdraget).

8 ibid. s. 37 (punkt 4.3.5.1 Regulering av kommunikasjonsmåte).
} 
ordlyden i lys av selskapenes behov for fleksibilitet og effektivitet, er det følgelig tale om en vurdering hvor dette må vektes mot hensynet til sikkerhet for at budskapet kommer til aksjonærens kunnskap.

Et annet spørsmål er om aksjelovens bestemmelser hvor kravet til «betryggende måte» finnes, må anses oppfylt så lenge informasjonen er kommet til selskapsaktørenes kunnskap. Ordlyden stiller krav om at informasjonen må være formidlet på en betryggende «måte». En alminnelig forståelse tilsier at vurderingen er om gjennomføringen har vært tilstrekkelig sikker og ikke hva som rent faktisk er det endelige resultatet. Er eksempelvis sensitive forretningshemmeligheter formidlet gjennom selskapsaktørens offisielle profilside på Facebook, vil dette etter ordlyden, selv hvor andre Facebook-brukere ikke leser innlegget, neppe kunne anses å være sendt på en «betryggende måte».

På den annen side fremkommer det i forarbeidene til inkassoloven at kravet til «betryggende måte» bør anses oppfylt «[h]vis en elektronisk meddelelse er sendt på en måte som gjør at den rent faktisk er kommet til mottakerens kunnskap ...» ${ }^{9}$. Etter inkassoloven fremstår følgelig kravet til «betryggende måte» å være oppfylt så lenge resultatet er at rette person får kunnskap om budskapet, uavhengig av gjennomføringsmåten. Dette kan tillegges vekt som følge av eRegelprosjektet.

Inkassolovens forarbeider kan derimot vanskelig tillegges avgjørende vekt, ettersom det i aksjeloven gjør seg gjeldende særegne hensyn. For selskapsaktørene er det ikke bare vesentlig at informasjonen kommer til rette adressats kunnskap, men at dette også ikke kommer til tredjepersoners kunnskap hvis hensikt kan være å skade selskapets eller selskapsaktørenes interesser. Det er også vesentlig at informasjonen som formidles, ikke blir utsatt for manipulasjon slik at ut $\varnothing v e l s e n$ av selskapsrettigheter og -plikter kan undergraves. Følgelig er det nærliggende å si at det i aksjeselskapsforhold har en betydning hvordan og dermed på hvilken måte informasjonen blir formidlet.

Vurderingen av om måten det er kommunisert på har vært «betryggende», kan sies å bestå av to deler. I første rekke vil det avhenge av å stadfeste en terskel. Denne må aldri settes så høyt at det i realiteten er umulig å tilfredsstille sikkerhetskravet. Dersom terskelen settes så høyt at vilkåret i realiteten ikke kan oppfylles, vil det kunne undergrave revisjonsarbeidet om å fremme bruken av ekommunikasjon ved å risikere at færre selskaper benytter seg av dette. I den konkrete sak må derfor terskelen være en reell og oppnåelig størrelse for selskapene.

\footnotetext{
${ }^{9}$ Prop. 6 L (2016-2017) s. 20 (punkt 3.4.1 Varsel om tvangsfullbyrdelse og inkasso).
} 
Ved stadfestingen av terskelen kan det spørres om hvilke momenter som kan bidra til å sette denne. Et relevant aspekt er at behovet, ønske og bruken av ekommunikasjon kan variere fra selskap til selskap. Selskapenes individuelle forhold vil derfor ofte spille en viktig rolle i vurderingen, herunder selskapets størrelse, formål og aksjonærsammensetning. For eksempel vil det kunne stilles andre krav til sikkerhet i finansforetaket med flere titalls aksjonærer, enn for frisørsalongen i kjelleren til ekteparet Ås som sammen eier aksjene og alene drifter selskapet.

Terskelen vil samtidig kunne variere alt etter meldingens karakter og innhold. Det vil stilles strengere krav til sikkerhet ved kommunisering av sensitiv informasjon enn ved formidling av ikke-sensitiv art. Eksempelvis stilles det normalt strenge krav til sikkerhet ved kommunisering av informasjon med rettsvirkninger for selskapsaktørene. Videre vil meldinger av konkurransemessig betydning kunne kreve hemmelighold, for eksempel ved formidling av forretningshemmeligheter. Likeledes vil også informasjonsutveksling i granskningssaker eller lignende gi behov for at informasjon ikke lekkes utenfor selskapet.

Når det er klargjort hva som er terskelen for kravet til «betryggende måte», vil man i andre rekke gå over til selve vurderingen av om den valgte metoden å kommunisere på har vært tilstrekkelig sikker. Sentralt i denne delen av vurderingen er om tiltakene som ble eller ikke ble foretatt i forbindelse med måten å ekommunisere på, var tilstrekkelig sikker i lys av terskelen. Eksempelvis vil man lettere anse ukrypterte e-poster med sensitiv informasjon å være sendt på en «betryggende måte» i frisørsalongen til ekteparet Ås, enn hvor finansforetaket sender ukrypterte e-poster om vesentlige forretningshemmeligheter til sine aksjonærer.

Videre, i vurderingen av om terskelen er nådd i den konkrete saken, vil et sentralt hensyn være notoritet. Ved en senere tvist om hva som er blitt kommunisert mellom partene, vil det kunne være behov for at kommunikasjonen kan etterprøves. Det er da viktig at man kan «dokumentere kommunikasjonens innhold, når og hvordan den foregikk, samt hvem som er avsender og mottaker» ${ }^{10}$. Behovet for notoritet er imidlertid lavere ved informasjonsutveksling uten rettsvirkninger. ${ }^{11}$

Momentene nevnt ovenfor er ikke ment som en uttømmende oppramsing av hva som kan trekkes inn i vurderingen av om ekommunikasjonen har forekommet på en «betryggende måte», men disse vil ofte stå sentralt. Det beror på den konkrete sak hva som kan trekkes inn og vil kunne variere etter omstendighetene.

\footnotetext{
${ }^{10}$ Prop. 112 L (2016-2017) s. 36 (punkt 4.3.5 Departementets vurdering).

11 ibid. s. 38 (punkt 4.3.5.1 Krav til kommunikasjonsmåte).
} 


\subsection{Forholdet til personvernreglene}

Ved bruken av elektroniske løsninger og hjelpemidler i selskapskommunikasjonen vil det ofte være tale om utveksling av personopplysninger. Ulike kommunikasjonsformer kan være egnet til å identifisere fysiske selskapsaktører. Reglene om vern av fysiske personer i forbindelse med behandling av personopplysninger - personvernforordningen ${ }^{12}(« \mathrm{GDPR} »)$ - vil i slike tilfeller komme til anvendelse.

GDPR-reglene får imidlertid ikke innvirkning på hva som etter aksjeloven anses som «betryggende» kommunikasjonsmåte. Aksjeloven henviser ikke i ordlyden til at ekommunikasjon skal skje på en betryggende personvernmessig måte. Videre fremgår det i forarbeidene til inkassoloven $\S 3$ a at det $\mathrm{i}$ «betryggende måte» ikke siktes til «hvorvidt meddelelsen er sendt på en måte som er betryggende personvernmessig eller på annen måte. Slike spørsmål reguleres av annet regelverk» ${ }^{13}$. Dette må kunne gjelde tilsvarende med hensyn til aksjelovens regler som følge av eRegelprosjektet.

Selv om GDPR-reglene ikke har innvirkninger på hva som anses som «betryggende måte» etter aksjeloven, betyr det likevel ikke at selskapet kan se bort fra personvernreglene. GDPR gjelder som norsk lov, jf. lov 15. juni $2018 \mathrm{nr}$. 38 om behandling av personopplysninger («personopplysningsloven») § 1, og er ikke unntatt i aksjeloven. Reglene må derfor respekteres i likhet med $\emptyset$ vrig lovgivning. Brudd på GDPR vil dermed kunne få personvernsrettslige konsekvenser selv om dette ikke gir selskapsrettslige virkninger.

\footnotetext{
${ }^{12}$ Regulation (EU) 2016/679 of the European Parliament and of the Council of 27 April 2016 on the protection of natural persons with regard to the processing of personal data and on the free movement of such data, and repealing Directive 95/46/EC.

${ }^{13}$ Prop. 6 L (2016-2017) s. 47 (punkt 9.3 Til $§ 3$ a).
} 


\section{$3 \quad$ Kommunikasjon fra selskapet til aksjonærene}

\subsection{Innledning}

Aksjeloven § 1-7 (1) regulerer kommunikasjonen fra selskapet til aksjonærene og er ikke nærmere regulert i forskrift, jf. tredje ledd. Under punkt 3.2 vil det gis en redegjørelse av styrets rett til å bestemme kommunikasjonsmåten i forhold til plikten om å gi meldinger mv. på en «betryggende og hensiktsmessig måte», jf. § 1-7 (1) første og siste punktum. Den nærmere balansegangen mellom kravet til «hensiktsmessig» og «betryggende» måte drøftes deretter under punkt 3.3. Videre vurderes det under punkt $3.4 \mathrm{om}$, og i så fall i hvilke tilfeller, selskapet plikter å kontakte aksjonærene på andre måter hvor den fastsatte kommunikasjonsmåten ikke kan gjennomføres. Under punkt 3.5 gjøres det til slutt greie for hva det etter § 1-7 (1) andre punktum betyr at styret må informere aksjonærene $i$ «rimelig tid før ny kommunikasjonsmåte tas i bruk».

\subsection{Selskapets meldinger mv. til aksjonærene skal gis på den måten styret bestemmer}

Det følger av aksjeloven § 1-7 (1) første punktum at selskapets meldinger mv. til aksjonærene «gis på den måten styret bestemmer». Etter vanlig språkforståelse gis dermed styret kompetanse til å fastsette hvordan kommunikasjonen fra selskapet til aksjonærene skal foregå. Dette er en rett aksjonærene ikke kan reservere seg mot. Lovgiver har, som tidligere nevnt, opphevet aksjeloven $\S 18-5$ som ga aksjonærene reservasjonsrett i form av samtykkekrav. Videre fremgår det av Proposisjonen at det ikke ble foreslått «en generell reservasjonsrett for aksjeeiere» ${ }^{14}$.

Generalforsamlingen kan imidlertid instruere styret om hvordan selskapets meldinger mv. til aksjonærene skal gis. Organets posisjon som øverste selskapsmyndighet anses å gi slik instruksjonsrett, jf. asl. § 5-1 (1), og er samtidig presisert i Proposisjonen flere steder. ${ }^{15}$ Styret bestemmer derfor kun der generalforsamlingen ikke har bestemt noe annet. Likevel står styret fritt fra generalforsamlingens instrukser hvor det vil stride «mot lov eller mot selskapets vedtekter» å etterfølge disse, jf. § 6-28 (2). Dette innebærer blant annet at styret ikke plikter å etterfølge generalforsamlingens instrukser om en kommunikasjonsmåte som ikke er «betryggende og hensiktsmessig» etter $§ 1-7$ (1) siste punktum.

Det kan spørres om generalforsamlingen, i vedtektene, kan tilsidesette styrets lovbestemte rett. Dette beror på en konkret tolkning av om § 1-7 (1) første punktum er en deklaratorisk eller preseptorisk regel. Paragrafen gir ikke selv uttrykkelig adgang til tilsidesettelse, noe som kan

\footnotetext{
${ }^{14}$ Prop. 112 L (2016-2017) s. 40 (punkt 4.3.5.1 Reservasjonsrett).

15 ibid. s. 37 (punkt 4.3.5.1 Regulering av kommunikasjonsmåte) og s. 103 (punkt 10.1 Til § 1-7).
} 
tilsi at den er ment å være ufravikelig. En slik tolkning har støtte i juridisk teori, «ordlyden synes å stenge for dette» ${ }^{16}$.

Aksjelovens system fremstår videre å være at det gis uttrykkelig anvisninger der bestemmelser om kommunikasjon skal kunne fravikes gjennom selskapets vedtekter. Som eksempel gir $§ 5$ 11 a første punktum generalforsamlingen kompetanse til å fravike hovedregelen om at saker som skal behandles i generalforsamlingen skal sendes aksjonærene. Herunder kan det vedtektsfestes at «dokumenter som gjelder saker som skal behandles på generalforsamlingen», gjøres tilgjengelige på selskapets internettsider.

På den annen side er det ingen automatikk i at aksjelovens regler ikke skal kunne fravikes ved fravær av uttrykkelig adgang til å bestemme annet. Det må foretas en konkret tolkning av den enkelte bestemmelse. ${ }^{17}$ Regelen om styrets bestemmelsesrett er ikke ment å ivareta tredjepartsinteresser, og aksjonærene kan ha en klar formening om hvordan de ønsker at selskapskommunikasjonen skal foregå. Dette må kunne tillegges tung vekt; utgangspunktet er at aksjonærene, gjennom vedtektene, skal kunne bestemme hvordan selskapet drives, jf. prinsippet i lov 21. juni $1985 \mathrm{nr}$. 83 om ansvarlige selskaper og kommandittselskaper («selskapsloven») § 1-4.

Videre, dersom styret mener kommunikasjonsmåten ikke er «betryggende og hensiktsmessig», vil styret i kraft av sin plikt til å sørge for «forsvarlig organisering av virksomheten» måtte anbefale generalforsamlingen om å endre kommunikasjonsmåten, jf. asl. § 6-12 (1) andre punktum. Skulle ikke generalforsamlingen etterkomme anbefalingen, vil styret uansett ha en plikt til å fravike vedtektenes bestemmelser til fordel for en «betryggende og hensiktsmessig» kommunikasjonsform. Dette, sammenholdt med utgangspunktet som følger av selskapsloven $\S 1-4$, gir derfor gode grunner til å konkludere § 1-7 (1) første punktum som en deklaratorisk regel.

Et annet spørsmål er om styret kan «bestemme[...]» at aksjonærene plikter å holde den angitte kommunikasjonsplattformen oppdatert. Ordlyden i § 1-7 (1) første punktum knytter seg til «måten» å kommunisere på. En alminnelig ordlydsforståelse tilsier at styret har frihet til å fastsette at kommunikasjonen skal foregå gjennom en bestemt applikasjon, for eksempel direktemeldinger via WhatsApp eller e-post gjennom Outlook. En naturlig følge av å formidle informasjon over applikasjoner som dette, er at det til stadighet oppstår behov for oppdateringer.

\footnotetext{
${ }^{16}$ Aarbakke, Magnus, Asle Aarbakke, Gudmund Knudsen, Tone Ofstad og Jan Skåre, Aksjeloven og allmennaksjeloven. Lovkommentar, 4. utg., Oslo: Universitetsforlaget, 2017, s. 106 (note 1.3).

17 Andenæs, Mads Henry, Aksjeselskaper og allmennaksjeselskaper, 3. utg. ved Ole Andenæs, Stig Berge og Margrethe Buskerud Christoffersen, Oslo: M.H. Andenæs, 2016, s. 51 (punkt 6.5 Adgangen til å fravike loven i vedtektene).
} 
Det er en vitterlig kjensgjerning at manglende oppdateringer kan innebære sikkerhetsproblemer. Dette gjelder særlig ved større programvareoppdateringer eller unnlatelse av flere mindre oppdateringer. Styrets lovpålagte ansvar om å sørge for en «betryggende og hensiktsmessig» kommunikasjonsmåte gjør derfor at selskapet også må kunne «bestemme[...]» at aksjonærene plikter å oppdatere disse regelmessig og ved større oppdateringer.

Er en mindre andel av aksjonærene uenig i styrets bestemte kommunikasjonsmåte, slik at det ikke fås medhold i generalforsamling for instruksjon om endring, kan aksjonærene reise søksmål om å kjenne generalforsamlingens beslutning ugyldig. I så fall må kommunikasjonsbeslutningen være «egnet til å gi visse aksjeeiere en urimelig fordel på andre aksjeeieres eller selskapets bekostning», jf. asl. § 5-21. Imidlertid er ikke enhver fordel som kun tilkommer enkelte aksjonærer lovstridig. En naturlig forståelse av ordlyden tilsier at det må foretas en skjønnsmessig vurdering av om kommunikasjonsbeslutningen gir et «urimelig» fortrinn for noen aksjonærer som er til ulempe for andre. I denne sammenheng påpekes det i juridisk teori at en saklig begrunnet beslutning ikke vil være «urimelig» i lovens forstand. ${ }^{18}$

Som oftest vil aksjonærene og selskapets interesser i hva som er «betryggende og hensiktsmessig» kommunikasjonsmåte være sammenfallende. Det kan likevel tenkes tilfeller der de ulike aktørenes interesser avviker fra hverandre. Et eksempel på dette er der valget av kommunikasjonsform går på bekostning av minoritetsaksjonærer som ikke har råd til å anskaffe det nødvendige kommunikasjonsutstyret. Dersom det finnes billigere alternativer, vil et slikt valg ofte måtte anses å være «urimelig».

Det kan likevel påpekes at valget av en kommunikasjonsform som gir enkelte aksjonærer en «urimelig» fordel, sjeldent vil kunne anses «hensiktsmessig». Dette viser at det er en nær sammenheng mellom myndighetsmisbruksregelen i aksjeloven $\S 5-21$ og sikkerhetskravet i $\S 1-7$ (1) tredje punktum: Kommunikasjonsbeslutningen vil sjeldent være «betryggende og hensiktsmessig» dersom den samtidig er «urimelig» overfor enkelte aksjonærer på bekostning av andre.

Videre kan det tenkes situasjoner hvor selskapet sender elektroniske meldinger mv. til aksjonærene, men uten å ha benyttet kompetansen til å fastsette hvordan selskapskommunikasjon skal foregå, eller i et enkelttilfelle bruker en annen ekommunikasjonsmåte enn det som er bestemt. Spørsmålet er om selskapets meldinger mv. har rettsvirkninger i disse tilfellene, det vil si om fastsettelsesregelen i § 1-7 (1) første punktum i realiteten er en ordensforskrift. En naturlig forståelse av at selskapets meldinger mv. «gis på den måten styret bestemmer» kan tale for

\footnotetext{
${ }^{18}$ Bråthen, Tore, Norsk lovkommentar, Gyldendal Rettsdata, «Kommentar til aksjeloven» § 5-21 note 890 hentet 18.10.2019, noten er sist hovedrevidert 06.04.2014 og sist endret 05.04.2018.
} 
at ekommunikasjon ikke kan anvendes før det fastsettes av styret, og i så fall kun på den måten som er bestemt, for å kunne ha rettslige virkninger.

På den annen side angir ikke bestemmelsen at informasjonen skal eller må gis på den fastsatte måten. En kontekstuell tolkning i lys av § 1-7 (1) siste punktum tilsier videre at det må sies å være likegyldig hvilke kommunikasjonsmåter som anvendes, så lenge informasjonen kommer til aksjonærenes kunnskap på en «betryggende og hensiktsmessig måte». I forarbeidene til opphevede $§ 18-5$ var det også klart forutsatt at de foreslåtte kravene til bruk av ekommunikasjon «i de fleste tilfeller er ordensbestemmelser ${ }^{19}$, slik at elektroniske meldinger mv. som var sendt uten uttrykkelig samtykke fortsatt ville kunne ha rettsvirkninger. Aksjeloven § 1-7 (1) kan vanskelig sies å gi utslag for en annen regel. Formålet med endringen var å tydeliggjøre og regulere likestillelsen av ekommunikasjon med tradisjonell kommunikasjon, ikke å sette begrensninger på effektiv kommunikasjon som en ordensregel vil kunne fremme. I juridisk teori er det videre argumentert for at regelen er en ordensforskrift. ${ }^{20}$

Det må etter dette kunne legges til grunn at elektroniske meldinger mv. som formidles til aksjonærene utover det som er bestemt av styret, eller hvor styret ikke har fastsatt noe om kommunikasjonsmåten, fortsatt vil kunne ha rettsvirkninger. «En melding sendt som e-post kan [derfor] ha rettsvirkninger selv om styret har fastsatt at meldinger til aksjeeierne skal sendes som vanlig post» ${ }^{21}$. Avgjørende er om meldingen mv. er kommet til aksjonærens kunnskap og at formidlingen for øvrig har skjedd på en «betryggende og hensiktsmessig måte».

Det kan spørres om elektroniske meldinger mv. som sendes utover det som er bestemt av styret eller hvor kommunikasjonsmåten ikke er fastsatt, for å anses å ha blitt sendt på en «betryggende og hensiktsmessig måte», forutsetter en form for samtykke fra aksjonærene for å kunne ha rettsvirkninger. Spørsmålet løses ikke uttrykkelig i § 1-7 (1). En naturlig forståelse av at informasjonsformidlingen skal være «hensiktsmessig» taler for at aksjonærene må kunne forutse hvor meldinger mv. vil kunne sendes før det kan ha rettsvirkninger. Dermed taler ordlyden for at selskapet, dersom annet ikke er bestemt ved styrebeslutning, må innhente samtykke til bruk av eventuelle andre former for ekommunikasjon.

Imidlertid er ikke aksjeloven til hinder for bruk av elektroniske løsninger hvor loven krever at meldinger mv. skal være eller gis skriftlig, jf. § 1-6 (2). En kontekstuell tolkning tilsier derfor, som følge av lovens teknologinøytrale løsning, at kravet til «betryggende og hensiktsmessig måte» må kunne være oppfylt selv hvor det ikke innhentes samtykke fra aksjonærene. Når

\footnotetext{
${ }^{19}$ Ot.prp. nr. 108 (2000-2001) s. 47 (punkt 3.6.2.3 Departementets vurdering).

${ }^{20}$ Aarbakke m.fl. (2017) s. 106 (note 1.2).

${ }^{21}$ ibid.
} 
formålet med lovrevisjonen nettopp var å fjerne alle rettslige hindringer for bruk av ekommunikasjon, herunder ved å fjerne samtykkekrav for styrets rett til å fatte beslutning om bruk av ekommunikasjonsmåter, må dette kunne tillegges avgjørende vekt.

Innhentelse av samtykke kan dermed ikke sies å være er et absolutt krav for å anse kommunikasjonsmåten som «betryggende og hensiktsmessig» hvor elektroniske meldinger mv. sendes utover det som er bestemt av styret, eller hvor kommunikasjonsmåten ikke fra før av er fastsatt. Derimot må det, i vurderingen av om kravet til «betryggende og hensiktsmessig måte» er oppfylt, antas å være et sentralt moment om samtykke er innhentet eller ikke. Kommunikasjonsmåten vil lettere anses å være «betryggende og hensiktsmessig» hvor samtykke foreligger enn hvor dette ikke er innhentet

Det må kunne være tilstrekkelig for selskapet å vise til et indirekte samtykke. Et indirekte samtykke kan sies å være gitt dersom aksjonæren har oppgitt en «digital adresse» i aksjeeierboken, jf. asl. § 4-5 (2), slik at selskapet kan bruke denne adressen til å sende elektroniske meldinger mv. Det kan videre tenkes at kommunikasjon gjennom bruk av adressene i aksjeeierboken, er det eneste som kan forutses av aksjonærene når dette er oppgitt. Da vil meldinger mv. til andre adresser enn det som er oppgitt, vanskelig være en måte som kan anses som «betryggende og hensiktsmessig». Dette er også antatt i juridisk teori. ${ }^{22}$

Et indirekte samtykke kan videre foreligge ved konkludent atferd. Hvor selskapet for eksempel benytter en alminnelig tilgjengelig kommunikasjonsmåte som e-post eller publikasjon på selskapets intranett, uten å møte protester fra aksjonærene, vil dette kunne være tilstrekkelig konkludent atferd. Manglende protester kan imidlertid ikke anses ensbetydende som et indirekte samtykke. Uvanlige former for ekommunikasjon kan ikke sies å gi selskapet en berettiget forventning om at aksjonæren har samtykket i å motta meldingen mv. på en slik måte, for eksempel hvor et varsel sendes via spillapplikasjoner som Wordfeud der aksjonæren har en brukerkonto.

Dersom det oppstår tvist om kommunikasjonsmåten har vært «betryggende og hensiktsmessig», er spørsmålet videre hvem av partene - aksjonæren eller selskapet - som har bevisbyrden. Det påpekes at behandlingen ikke tar for seg spørsmålet om bevisbyrde i straffesaker etter aksjeloven § 19-1 (1). Utgangspunktet etter alminnelige prosessregler i norsk rett «er at saksøker har bevisbyrden, dvs. at eventuell tvil om faktum i en sak går i disfavør av saksøker» ${ }^{23}$.

\footnotetext{
${ }^{22}$ Aarbakke m.fl. (2017) s. 107 (note 1.7).

${ }^{23}$ Ot.prp. nr. 77 (2000-2001) s. 90 (punkt 12.2.1 Bakgrunn).
} 
Bevishensyn gjør det imidlertid nærliggende å pålegge selskapet bevisbyrden i en eventuell tvist om kommunikasjonsmåten har vært «betryggende og hensiktsmessig», også hvor aksjonæren er saksøker (omvendt bevisbyrde). Styret, gjennom styreresolusjoner og -protokoller, vil lettere kunne dokumentere de faktiske forhold og står dermed nærmest til å sikre bevis og notoritet i forbindelse med den valgte kommunikasjonsmåten. Likevel, som presisert av Høyesterett, vil bevisbyrden kunne forandre seg under sakens gang, eksempelvis dersom selskapet fremlegger vektige bevis og slik gjør det opp til motparten å sannsynliggjøre at kommunikasjonsformen ikke oppfyller lovens krav. ${ }^{24}$

\subsection{Krav om betryggende og hensiktsmessig kommunikasjonsmåte}

Kravet til «betryggende» måte i aksjeloven $§ 1-7$ (1) siste punktum innebærer en begrensning i styrets bestemmelsesrett og skiller seg ut ved at det også oppstiller et krav om «hensiktsmessig[het]». Dermed legger bestemmelsens ordlyd opp til en skjønnsmessig sikkerhetsvurdering om den fastsatte kommunikasjonsmåten er berettiget, hvor kravet til «betryggende og hensiktsmessig» måte må avveis mot hverandre. Som det presiseres i Proposisjonen, er kravet til betryggende kommunikasjonsmåte «primært foreslått for å ivareta notoritet og hensynet til aksjeeierne» ${ }^{25}$, mens «hensynet til selskapet ... [først og fremst] ivaretas ved hensiktsmessighetskravet» ${ }^{26}$. Selskapet må derfor normalt forsøke å finne en rimelig balanse mellom disse hensynene når det fastsetter kommunikasjonen i selskapet. ${ }^{27}$

Det kan stilles spørsmål ved om kravet til «betryggende og hensiktsmessig måte» forutsetter at meldingen mv. kan leses. En naturlig forståelse av at ekommunikasjonen må kunne foretas på en «betryggende og hensiktsmessig måte» tilsier at meldinger mv. også kan gis muntlig, ettersom det vil kunne være fleksibelt for selskapet hvor det ikke er betenkelig av sikkerhetsmessige hensyn. Lovsystematikken taler videre for at muntlige kommunikasjonsmåter må kunne benyttes i de tilfeller aksjeloven selv ikke krever skriftlighet, slik det blant annet gjør i §§ 5-10 (1) første punktum, 13-12 (2) tredje punktum og 13-23 (2) nr. 3 fjerde punktum. I Proposisjonen er det også lagt til grunn, med avgjørende vekt på selskapets behov for fleksibilitet, at meldinger mv. kan gis muntlig. ${ }^{28}$

På den annen side mente utvalget som lå til grunn for Proposisjonen (heretter «Utvalget») at det måtte gjelde krav om lesbar form og at dette fulgte av hensiktsmessighetskravet. ${ }^{29}$ Lesbarhet vil også kunne gjøre det enklere å ettergå kommunikasjonen med tanke på gransking eller

\footnotetext{
${ }^{24}$ Rt. 2007 s. 817 avsnitt 40.

${ }^{25}$ Prop. 112 L (2016-2017) s. 38 (punkt 4.3.5.1 Krav til kommunikasjonsmåte).

${ }^{26}$ ibid.

${ }^{27}$ Aarbakke m.fl. (2017) s. 106 (note 1.5).

${ }^{28}$ Prop. 112 L (2016-2017) s. 38 (punkt 4.3.5.1 Krav til kommunikasjonsmåte).

${ }^{29}$ NOU 2016: 22 s. 44 (punkt 5.7.3.2 Aksjeselskapets adgang til å gi meldinger mv. til aksjonærene).
} 
lignende hvor hensynet til notoritet står sentralt. Selv om dette gir gode grunner til å betrakte lesbarhet som et absolutt sikkerhetskrav, kan det vanskelig tillegges avgjørende vekt satt opp mot ordlyden, lovsystematikken og Proposisjonen. Følgelig er det ingen absolutt forutsetning for å kommunisere på en «betryggende og hensiktsmessig måte» at elektroniske meldinger mv. kan leses.

Når det gjelder bruk av dyre og kompliserte kommunikasjonsmåter, vil det avhenge av det enkelte tilfelle om slik bruk oppfyller kravet til «betryggende og hensiktsmessig måte». Dyre og kompliserte kommunikasjonsmåter indikerer blant annet kvalitet og derav god sikkerhet, som kan gjøre det egnet for selskaper hvor behovet for sikker informasjonsformidling står sterkt. Bruken av dyre og kompliserte kommunikasjonsmåter må imidlertid ikke vanskeliggjøre aksjonærens muligheter til å ivareta sine interesser. Dersom aksjonærene direkte forhindres fra å gjøre dette, vil det etter ordlyden vanskelig kunne sies å være tale om en «betryggende og hensiktsmessig» kommunikasjonsmåte. Dette er også bakgrunnen for at det i Proposisjonen ikke anbefales å stille slike vilkår. ${ }^{30}$

\subsection{Selskapets aktivitetsplikt hvor elektronisk kommunikasjon ikke kan gjennomføres som fastsatt av styret}

Det kan være flere grunner til at selskapet ikke får ekommunisert til aksjonæren på den fastsatte måten. For eksempel kan det være at selskapet mottar et automatisk svar om at e-posten ikke lenger er i bruk, eller det kan være at vedkommendes digitale adresse ikke er oppgitt for selskapet. I slike tilfeller plikter selskapet å kontakte aksjonæren på annen måte. Denne plikten kan sies å følge av styrets rolle som selskapets forvaltningsorgan etter aksjeloven § 6-12 (1) og bunner i aksjonærens grunnleggende rett til å motta meldinger mv. for å kunne ivareta sine rettigheter. I Proposisjonen kommer det også frem at selskapet har «en plikt til å finne løsninger som sikrer at aksjeeierne kan ivareta sine aksjeeierrettigheter» ${ }^{31}$ i de tilfellene der aksjonæren ikke har digital adresse.

Selskapet har likevel ikke plikt til å oppdatere aksjeeierboken i forbindelse med ekommunikasjon. I aksjeloven $§ 4-5$ står det ingenting om en slik plikt. Det nevnes også i Proposisjonen at man så det som et byrdefullt ansvar for selskapet om det skulle ha ansvaret for oppdateringer, spesielt hvor selskapet har mange aksjonærer. ${ }^{32}$ Samme sted presiseres det at aksjonærene står nærmest til å melde fra om digitale adresseendringer. Selskapet må derfor, hvor det ikke har mottatt melding om endring av digitaladresse, som et utgangspunkt kunne stole på at det som

\footnotetext{
${ }^{30}$ Prop. 112 L (2016-2017) s. 38 (punkt 4.3.5.1 Krav til kommunikasjonsmåte).

31 ibid. s. 39 (punkt 4.3.5.1 Reservasjonsrett).

${ }^{32}$ ibid. s. 39 (punkt 4.3.5.1 Elektronisk adresse).
} 
står i aksjeeierboken er riktig. Benyttes den oppgitte digitaladressen i selskapskommunikasjonen, må det følgelig anses å være en presumsjon for at meldingen mv. er sendt på en «betryggende og hensiktsmessig måte».

Får ikke selskapet sendt elektroniske meldinger mv. på den fastsatte måten, eller det er klart for selskapet at aksjonærens oppgitte digitaladresse i aksjeeierboken ikke er i bruk, plikter selskapet å bruke andre kommunikasjonsadresser som det skulle ha kjennskap til. Dette kan for eksempel være en eventuell annen «digital adresse ... eller bostedsadresse og eventuelt postadresse», jf. § 4-5 (2). Denne plikten kan sies å følge av aksjelovens systematikk, ettersom selskapet skal sende meldinger mv. til «aksjeeiere med kjent adresse» (kursivert her), jf. blant annet $\S$ 5-5 (3), 5-10 (1) første punktum og 16-6 (4) første punktum. Må tradisjonelle måter anvendes enda det er bestemt at kommunikasjonen skal foregå elektronisk, kan selskapet i så fall «kreve betaling for faktiske kostnader, herunder porto og medgått arbeidstid ${ }^{33}$. Selv om det ikke er en plikt, bør aksjonærene samtidig gjøres «oppmerksom på at selskapet ikke når frem på den oppgitte [digitale] adressen» ${ }^{34}$.

Spørsmålet er om selskapets aktivitetsplikt kan oppfylles ved å kommunisere elektronisk via aksjonærens nærstående, jf. asl. § 1-5 (1), eksempelvis ektefelle og barn. I § 1-7 (1) første punktum står det at meldinger mv. gis «til aksjeeierne». En naturlig forståelse tilsier at meldinger mv. ikke kan være gitt til aksjonæren dersom det gis til andre enn aksjonæren selv, herunder nærstående. Ordlyden har støtte i Proposisjonen, hvor man så kommunikasjon via nærstående som «uhensiktsmessig, og i verste fall ... lovstridig ...» ${ }^{35}$. Det er også risiko for at budskapet misbrukes av en nærstående eller ikke blir videreformidlet til aksjonæren.

Imidlertid mente Utvalget at selskapet berettiget kunne kommunisere til «for eksempel familiemedlemmer eller aksjonærens arbeidsplass» ${ }^{36}$. Utvalgets uttalelser taler dermed for at selskapet har fleksibilitet til å kommunisere via aksjonærens nærstående. Satt opp mot det som følger av en alminnelig ordlydsforståelse, uttalelsene i Proposisjonen og risikobetraktninger, kan Utvalgets uttalelser likevel ikke tillegges avgjørende vekt. Selskapet må derfor finne andre måter å kontakte aksjonæren på enn ved å sende meldinger mv. via dennes nærstående.

\footnotetext{
${ }^{33}$ Prop. 112 L (2016-2017) s. 39 (punkt 4.3.5.1 Reservasjonsrett).

34 ibid. s. 39 (punkt 4.3.5.1 Elektronisk adresse).

35 ibid. s. 39 (punkt 4.3.5.1 Reservasjonsrett).

${ }^{36}$ NOU 2016: 22 s. 46 (punkt 5.7.3.2 Aksjeselskapets adgang til å gi meldinger mv. til aksjonærene).
} 


\subsection{Styret skal informere aksjonærene $\mathrm{i}$ rimelig tid før ny kommunikasjonsmåte tas i bruk}

Aksjeloven § 1-7 (1) andre punktum gir etter sin ordlyd anvisning på en konkret og skjønnsmessig vurdering av om varslingen om ny kommunikasjonsmåte er gitt $\mathrm{i}$ «rimelig tid» før den tas i bruk. I rimelighetsvurderingen vil det stå sentralt om aksjonærene er gitt «mulighet til å innrette seg, samt fremme innsigelser til kommunikasjonsmåten» ${ }^{37}$. Først da vil formålet med informasjonsplikten om å gi aksjonærene «en reell forutsetning for å ivareta sine aksjeeierrettigheter» ${ }^{38}$ være ivaretatt. Blir det for eksempel fastsatt at deler av selskapskommunikasjonen skal foregå på Skype, må aksjonærene følgelig få tid og anledning til å laste ned applikasjonen, lage egen bruker, rette eventuelle innsigelser og til å gjøre styret oppmerksom på eventuelle utfordringer med kommunikasjonsmåten.

Videre følger det av andre punktum at selskapet «skal informere» aksjonærene før den nye kommunikasjonsmåten tas i bruk. Ettersom styrets fastsettelseskompetanse etter første punktum er en ordensfoskrift, er det nærliggende å si at selskapet kan informere på den måten som den finner mest tjenlig, forutsatt at varslingen skjer på en «betryggende og hensiktsmessig måte» etter siste punktum. Aksjonærene kan imidlertid sies å ha en rimelig forventning om å bli varslet på den måten som styret har bestemt etter første punktum. Utgangspunktet må derfor være at styret varsler på den fra før av bestemte kommunikasjonsmåten. Dette presiseres i Proposisjonen, hvor det fremheves at varslingen anses tilstrekkelig dersom det skjer «på den måten selskapet vanligvis kommuniserer med aksjeeierne på» ${ }^{39}$. Er ikke kommunikasjonsmåten fastsatt, vil selskapet kunne lene seg på adressene som eventuelt står oppført i aksjeeierboken.

Det kan imidlertid spørres om det er et absolutt vilkår for å endre kommunikasjonsmåten at aksjonærene varsles om dette. En naturlig forståelse av ordlyden i § 1-7 (1) andre punktum tilsier at varslingsplikten er absolutt, ettersom selskapet «skal» varsle aksjonærene. Varslingsregelen må i tillegg anses som en enkel regel å forholde seg til i praksis. Regelen ivaretar også aksjonærens forutberegnelighet ved å kunne innrette seg til den nye og kommende kommunikasjonsmåten av hensyn til utøvelse av aksjonærrettigheter.

På den annen side må aksjonærens samtykke om å motta fremtidige meldinger mv. på den nye kommunikasjonsmåten kunne sies å frita styret fra varslingsplikten. Dette antas i juridisk teori, det må «kunne gjøres unntak uten forhåndsvarsel hvis berørte aksjeeiere samtykker til å motta en melding e.l. på annen måte enn det styret har fastsatt for selskapet» ${ }^{40}$. I slike tilfeller vil

\footnotetext{
${ }^{37}$ Prop. 112 L (2016-2017) s. 103 (punkt 10.1 Til § 1-7).

${ }^{38}$ ibid. s. 37 (punkt 4.3.5.1 Informasjonsplikt).

${ }^{39} \mathrm{ibid}$.

${ }^{40}$ Aarbakke m.fl. (2017) s. 106 (note 1.4).
} 
nettopp aksjonærens forutberegnelighet, og derav varslingsregelens formål, være ivaretatt. Gode grunner gjør det derfor nærliggende å si at varsling om ny kommunikasjonsmåte ikke er et absolutt vilkår i tilfellene hvor aksjonæren har samtykket til endringen.

Neste spørsmål er i hvilke tilfeller selskapet plikter å «informere» aksjonærene om «ny kommunikasjonsmåte», jf. § 1-7 (1) andre punktum. Etter alminnelig språkforståelse aktiveres varslingsplikten i de tilfeller selskapet beslutter å bruke andre informasjonsformidlingsmetoder enn det som allerede anvendes i selskapet. Antitetisk tolket vil ikke varslingsplikten utløses hvor det fortsatt er tale om den samme kommunikasjonsmåten, om enn i en noe annen form. Beslutningen om å endre kommunikasjonsmåten fra e-post til SMS vil derfor kunne sies å være en «ny kommunikasjonsmåte» som aktiverer varslingsplikten. Et bytte fra applikasjonen Outlook til Gmail, som begge åpner for kommunikasjon ved e-post, vil derimot ikke anses å aktivere varslingsplikten hvor e-post fra før av er en bestemt måte å kommunisere på.

Videre er spørsmålet om oppdateringer av en plattform som benyttes til selskapskommunikasjonen, kan anses som «ny kommunikasjonsmåte» og derved aktivere varslingsplikten. Selv om store og omfattende oppdateringer av et kommunikasjonsmedium kan medføre vesentlige endringer, tilsier en alminnelig ordlydsforståelse at det vanskelig kan sies å aktivere varslingsplikten med mindre selve «måten» å kommunisere på forandres, erstattes eller lignende og derved blir «ny». Hvis derimot oppdateringen av den anvendte kommunikasjonsapplikasjonen åpner for alternative måter å kommunisere på og som selskapet ønsker å ta i bruk, vil dette naturlig anses som en «ny» kommunikasjonsmåte. Er for eksempel kommunikasjonsmåten bestemt å foregå via e-post ved hjelp av Outlook, vil aktivitetsplikt foreligge dersom en Outlookoppdatering åpner for en ny gruppechatte-funksjon som selskapet ønsker å benytte seg av. 


\section{$4 \quad$ Kommunikasjon fra aksjonærene til selskapet}

\subsection{Innledning}

Kommunikasjon fra aksjonærene til selskapet reguleres av aksjeloven § 1-7 (2) og er heller ikke nærmere regulert i forskrift, jf. tredje ledd. Det fremkommer av andre ledd at aksjonærenes meldinger mv. til selskapet «alltid [kan] sendes til selskapets forretningsadresse, og til digital adresse og postadresse som selskapet har oppgitt». I inneværende kapittel vil det drøftes om plikten til «alltid» å akseptere elektroniske meldinger mv. fra aksjonærene gjelder absolutt (punkt 4.2). Deretter i hvilken grad selskapet kan avskjære elektroniske meldinger mv. som ikke sendes til selskapets oppgitte digitaladresse (punkt 4.3). Og til slutt om selskapet kan avskjære meldinger mv. som ikke er sendt fra aksjonærenes egne digitale adresser (punkt 4.4).

\subsection{Aksjonærene kan alltid kommunisere til selskapets oppgitte digitale adresse}

Aksjonærene kan «alltid» sende meldinger mv. til «selskapets ... digital adresse ... som selskapet har oppgitt». Selv om begrepet «digital adresse» står i entall, er det naturlig å tolke ordlyden slik at selskapet kan oppgi flere digitale adresser. Dette er også klart forutsatt i Proposisjonen. ${ }^{41}$ For selskapet kan det også være praktisk å ha flere digitaladresser til ulike formål, for eksempel én til ordrebestilling, en annen til kundeservice og en tredje spesifikt til kommunikasjon med aksjonærene.

Det kan spørres om det foreligger en rett for selskapet til å avskjære meldinger mv. som er sendt til én av selskapets flere oppgitte digitaladresser, men som selskapet uttrykkelig har bedt aksjonærene om å ikke benytte. En naturlig forståelse av at aksjonærene «alltid» kan sende meldinger mv. til selskapets oppgitte digitale adresser kan tyde på at avskjæringsgrunnlag ikke foreligger.

På den annen side er det i Proposisjonen åpnet for en slik avskjæringsadgang, forutsatt at det som «et minimum oppgis hvilken e-postadresse som skal benyttes» ${ }^{42}$, eventuelt andre digitaladresser. For selskapet kan det også være byrdefullt og uoversiktlig å måtte forholde seg til alle oppgitte digitaladresser i forbindelse med meldinger mv. fra aksjonærene. Med avgjørende vekt på selskapets behov for fleksibilitet og effektivitet, må derfor meldinger mv. fra aksjonærene som sendes i strid med selskapets instrukser kunne avskjæres. Forutsetningen må imidlertid være at selskapet har tydeliggjort hvilken digitaladresse de ulike henvendelsene må rette seg

\footnotetext{
${ }^{41}$ Prop. 112 L (2016-2017) s. 40 (punkt 4.3.5.2 Aksjeeiers kommunikasjon med aksjeselskapet).

${ }^{42}$ ibid.
} 
til. For eksempel vil selskapet kunne avskjære meldinger som ikke sendes til selskapets oppgitte digitaladresse forbeholdt til kommunikasjon med aksjonærene. Selskapet kan også avskjære svar på automatisk genererte meldinger hvor det uttrykkelig bes om å ikke svare (såkalt noreply), typisk «dette er en automatisk generert e-post, vennligst ikke svar på denne e-posten».

Videre er spørsmålet om selskapet har rett til å avskjære meldinger mv. som sendes til «selskapets forretningsadresse» og «postadresse» når styret har bestemt at kommunikasjonen skal foregå til «digital adresse». At aksjonærene «alltid» kan benytte selskapets forretnings- og postadresser synes å stenge for en avskjæringsadgang i slike tilfeller. Dette har støtte i lovrevisjonens intensjon om å ikke erstatte elektroniske kommunikasjonsmåter med tradisjonelle kommunikasjonsmåter, men å likestille disse. Det kan på den annen side være praktisk og miljøbesparende for selskapet å kreve at aksjonærene forholder seg utelukkende til digitale meldinger, men veid opp mot den klare ordlyden i § 1-7 (2) kan dette vanskelig tillegges avgjørende vekt. Følgelig kan ikke selskapet sies å ha rett til å avskjære meldinger mv. som sendes til selskapets oppgitte forretnings- eller postadresse når kommunikasjonen er bestemt å foregå på elektroniske måter.

Selskapet kan heller ikke avskjære meldinger mv. fra aksjonærene som sendes til selskapets oppgitte «forretningsadresse» eller «postadresse» når det er regulert i vedtektene at kommunikasjonen utelukkende skal foregå til «digital adresse». Aksjeloven § 1-7 (2) åpner ikke for en slik reguleringsadgang. Videre synes en adgang til «alltid» å kunne bruke selskapets forretnings- og postadresse å verne utøvelsen av aksjonærrettigheter, typisk hvor teknologien svikter eller ikke er anvendbar. Eksempelvis vil retten til å sende melding om spørsmål man ønsker å få behandlet på generalforsamlingen, jf. asl. § 5-11 første og andre punktum, undergraves om aksjonæren ikke kan bruke det lokale postkontoret når vedkommende ferierer på fjellhytten som er uten internettforbindelse og telefonsignaler. Retten til «alltid» å kunne sende meldinger mv. til selskapets oppgitte forretnings- og postadresser må derfor anses å være en preseptorisk regel som ikke kan fravikes i vedtektene.

\subsection{Elektroniske meldinger mv. som ikke sendes til selskapets oppgitte digitale adresse}

Spørsmålet er om selskapet kan avskjære elektroniske meldinger mv. som ikke sendes til selskapets oppgitte «digital adresse», for eksempel private meldinger til styrelederens e-postadresse. En alminnelig forståelse av at aksjonærene alltid «kan» sende meldinger mv. til de adresser som fremkommer av $\S 1-7$ (2), tilsier at aksjonærene har frihet til å ekommunisere også 
utover selskapets oppgitte «digital adresse». Likevel har selskapet, som fremhevet i Proposisjonen, en «svært snever» ${ }^{43}$ adgang til å avskjære meldinger mv. som sendes til andre digitaladresser enn det som er oppgitt. Terskelen for å kunne avskjære er dermed høy, men vil være nådd ved meldinger mv. i form av kommentarer på ulike sosiale medier som Facebook og Twitter. I Proposisjonen ble slike allment tilgjengelige kommunikasjonsmåter ansett å favne for vidt til å kunne aksepteres, i tillegg til å kunne medføre unødvendige konflikter. Det kunne også være egnet til å undergrave selskapets kompetanse til å fastsette kommunikasjonsmåten. ${ }^{44}$

Utenom elektroniske meldinger mv. som sendes via allment tilgengelige kommunikasjonsmidler, vil det bero på en skjønnsmessig vurdering av om avskjæringsterskelen er nådd. Avgjørende må være om meldingen mv. fra aksjonæren anses å være sendt på en «betryggende og hensiktsmessig måte», sml. § 1-7 (1) siste punktum. En avskjæringsadgang vil derfor kunne foreligge hvor hensynet til selskapet, etter en avveining, gjør seg gjeldende med styrke til fordel for hensynet til aksjonærene. For eksempel vil hensynet til selskapet vanskelig kunne tillegges tung vekt hvor aksjonæren i et enkelttilfelle kontakter styrets leder, ved forutgående kontakt med daglig leder eller gjør dette fordi selskapet har oppgitt feil digitaladresse. Samme må være tilfelle hvor meldingen mv. angår utøvelse av sentrale aksjonærrettigheter, ettersom aksjonærene «bør ... ha mulighet til å sende meldinger mv. på en måte som ikke vanskeliggjør ivaretakelsen av rettighetene» ${ }^{45}$. Som eksempel vil meldingen til styrelederens e-postadresse om utøvelse av forkjøpsrett, jf. § 4-23 (1), vanskeligere la seg avskjære sammenlignet med den rene opplysningen om at aksjonæren bringer en rådgiver på generalforsamlingen, jf. § 5-2 (3).

\subsection{Elektroniske meldinger mv. sendt av andre enn aksjonæren selv}

Problemstillingen er om meldinger mv. sendt til selskapets digitale adresse kan avskjæres hvor aksjonæren kommuniserer fra en annens digitaladresse enn sin egen. Som det følger av § 1-7 (2), plikter selskapet å akseptere «[a]ksjeeiernes meldinger mv.». En naturlig forståelse av ordlyden tilsier at meldinger mv. fra andre enn aksjonærene selv kan avskjæres av selskapet. Det er også risiko for at meldingen mv. stammer fra uvedkommende, som kan ha til hensikt å skade selskapets eller aksjonærens interesser.

På den annen side kan det være praktisk, effektivt og «hensiktsmessig» for både selskapet og aksjonæren å ikke avskjære slike meldinger mv. Dersom selskapet samtidig anser meldingen mv. å være sendt på en «betryggende» måte, må det kunne akseptere budskapet som sendes fra en annens digitaladresse på vegne av aksjonæren. Om beskjeden oppfyller sikkerhetskravet kan fremgå av konteksten, eksempelvis hvor en eldre aksjonær har fått hjelp av barn, barnebarn

\footnotetext{
${ }^{43}$ Prop. 112 L (2016-2017) s. 40 (punkt 4.3.5.2 Aksjeeiers kommunikasjon med aksjeselskapet).

${ }^{44}$ ibid.

${ }^{45}$ ibid.
} 
eller andre nærstående til å kommunisere via deres digitaladresser til selskapet. Er selskapet i tvil, kan det få oppklart om meldingen mv. er rettmessig ved for eksempel å be avsenderen fremlegge en fullmakt til å kommunisere på vegne av rette aksjonær. 


\section{$5 \quad$ Bruk av elektroniske hjelpemidler på generalforsamlingen}

\subsection{Innledning}

Generalforsamlingen skal som øverste selskapsorgan treffe viktige beslutninger både for selskapet og aksjonærene, eksempelvis valg av styremedlemmer, vedtektsendringer og om aksjonærenes forpliktelser i forhold til selskapet skal økes, jf. asl. henholdsvis §§ 6-3 (1), 5-18 og 5-20 (1) nr. 1. For å treffe slike beslutninger, er det nødvendig for generalforsamlingen å kommunisere og stemme over sakene som er til behandling. Gjennom §§ 5-7 og 5-11 b kan denne prosessen foregå elektronisk, for eksempel skriftlig ved sirkulasjon av dokumenter over e-post eller muntlig som video- eller telefonmøte.

Aksjeloven $§$ 5-7 hjemler adgangen for aksjonærene til å gjennomføre generalforsamlingen forenklet og uten fysisk møte, herunder utelukkende ved hjelp av elektroniske løsninger. Bestemmelsen i § 5-11 b hjemler, på sin side, adgangen for aksjonærene til å delta og stemme elektronisk på ordinær generalforsamling som i utgangspunktet holdes som et fysisk møte. ${ }^{46}$ Aksjeloven $\S 5-11$ b svarer også til de tilsvarende bestemmelsene i allmennaksjeloven $\S \S 5-8$ a og 5-8 b, som igjen gjennomfører aksjonærrettighetsdirektivet ${ }^{47}$ artikkel 8.

I punktene 5.2 og 5.3 vil problemstillingene som henholdsvis $\S$ 5-7 og 5-11 b reiser i forbindelse med ekommunikasjon, drøftes. Deretter, i punkt 5.4, ses det nærmere på spørsmål som oppstår hvor det foreligger teknologisk svikt under generalforsamlingen som hindrer utøvelse av aksjonærrettigheter.

\subsection{Forenklet generalforsamling som gjennomføres utelukkende ved hjelp av elektroniske hjelpemidler}

\subsubsection{Krav om at ingen aksjonærer motsetter seg forenklet behandling}

Et vilkår for å kunne avholde forenklet elektronisk generalforsamling, er at «ingen aksjeeiere motsetter seg det», jf. § 5-7 første punktum. Det følger av en alminnelig ordlydsforståelse at samtlige aksjonærer må samtykke om en forenklet behandling. Ordlyden oppstiller imidlertid ingen formkrav. Dette innebærer at det ikke må innhentes eksplisitt og dokumenterbart samtykke, men selskapet må likevel «på betryggende måte sikre[...] at ingen aksjeeiere motsetter

\footnotetext{
${ }^{46}$ Aarbakke m.fl. (2017) s. 382 (note 1.1).

${ }^{47}$ Directive 2007/36/EC of the European Parliament and of the Council of 11 July 2007 on the exercise of certain rights of shareholders in listed companies.
} 
seg den foreslåtte måten å holde generalforsamling på ${ }^{48}$. Forutsetningen er at samtlige aksjonærer forespørres, gis en rimelig frist for å kunne gi eventuelle tilbakemeldinger eller motsette seg forslaget, samt opplyses om at manglende tilbakemelding vil oppfattes som et samtykke. ${ }^{49}$ Det må også kunne sies, av hensyn til aksjonærene som har behov for et reelt samtykkegrunnlag, å være en forutsetning at det redegjøres for hvordan generalforsamlingen skal gjennomf $\varnothing-$ res. ${ }^{50}$

Videre kreves det ikke at samtlige aksjonærer må delta for å kunne avholde generalforsamlingen forenklet og utelukkende ved hjelp av elektroniske hjelpemidler. Dette følger av en naturlig forståelse av at det er tilstrekkelig å gi enhver «mulighet» til å delta, jf. § 5-7 nr. 1. I forarbeidene og juridisk teori er dette også lagt til grunn. ${ }^{51}$

\subsubsection{Krav om betryggende gjennomføringsmåte?}

Til forskjell fra adgangen til å delta elektronisk på generalforsamlingen etter $\S 5-11 \mathrm{~b}$, stilles det ikke noe eksplisitt krav om en «betryggende» gjennomføringsmåte i § 5-7. Selv om den faktiske likheten kan sies å gi samme behov for sikkerhet, er det likevel tydelig forutsatt i § 57 nr. 4 at generalforsamlingen «kan holdes uten å følge kravene i §§ 5-8 til 5-16». Sikkerhetskravet som følger av § 5-11 b er med det unndratt. Dette bygger på formålet med § 5-7 om å gi en «oppskrift på en enkel måte å holde generalforsamling på i små selskaper når alle aksjeeierne er enige om det» ${ }^{52}$. Generalforsamlingen er dermed gitt adgang til å se bort fra sikkerhetsreglene som følger av § 5-11 b når det avholder møte etter § 5-7.

Til tross for at det ikke gjelder et generelt krav om «betryggende» gjennomføringsmåte ved forenklet elektronisk generalforsamling, stiller $§ 5-7$ nr. 1 til 3 nærmere vilkår til gjennomf $\varnothing-$ relsen. Bestemmelsene setter visse minimumskrav til sikkerhet, blant annet krav til egnethet og notoritet. I fortsettelsen redegjøres det for $§ 5-7$ nr. 1 til 3.

Etter nr. 1 skal aksjonærene gis mulighet til å delta i behandlingen av saken på «egnet måte». En alminnelig forståelse av ordlyden tilsier at gjennomføringsmåten som velges, må gi aksjonærene anledning til å være elektronisk tilstede under behandlingen ved å kunne ta ordet og avgi stemme. Følgelig kan ikke elektronisk deltakelse på «egnet måte» sies å foreligge med mindre ordningen gjør at samtlige aksjonærer kan følge behandlingen, uttale seg og stemme på generalforsamlingen.

\footnotetext{
${ }^{48}$ Prop. 112 L (2016-2017) s. 105 (punkt 10.1 Til § 5-7).

49 ibid. s. 44 (punkt 5.1.1.4 Departementets vurdering).

${ }^{50}$ Aarbakke m.fl. (2017) s. 365 (note 1.1).

${ }^{51}$ Prop. 111 L (2012-2013) s. 110 (punkt 8.1 Til § 5-7) og Aarbakke m.fl. (2017) s. 366 (note 1.3).

52 Prop. 111 L (2012-2013) s. 110 (punkt 8.1 Til § 5-7).
} 
Hvor en aksjonær ønsker å delta elektronisk, men ikke har anledning til å delta som først forutsatt, plikter generalforsamlingen å legge til rette for at vedkommende får anledning til å delta på annen «egnet måte», jf. nr. 1. Dette kan sies å følge av en naturlig forståelse av at aksjonærene «skal» gis mulighet til å delta. I tillegg kan tilretteleggingsplikten sies å følge av aksjonærens grunnleggende rett til å delta på generalforsamlingen når man selv ønsker deltakelse. Tilrettelegging kan gjøres ved enkle tiltak som «å flytte møtetidspunktet eller legge til rette for at vedkommende kan holdes oppdatert og gis mulighet til å delta per telefon eller e-post» ${ }^{53}$.

Det følger av nr. 2 at ledelsen «skal» varsles for å «gis mulighet til å uttale seg om» generalforsamlingen bør avholdes forenklet og elektronisk. Spørsmålet er om varslingsplikten er et absolutt vilkår for å avholde møte etter § 5-7 eller om aksjonærene kan se bort fra varslingsregelen ved enighet om å ikke informere ledelsen. En alminnelig forståelse av at varsling «skal» gis, tilsier at varslingsplikten er et kumulativt vilkår som er nødvendig for å kunne avholde en forenklet og elektronisk generalforsamling. Dette har støtte i ledelsens rett til å delta, jf. § 5-4 (1), som kan bli undergravet om ikke ledelsen gjøres kjent med at det skal avholdes generalforsamling.

I Knudsen-utredningen, som lå til grunn for lovendringene, argumenterte man derimot for at ledelsens egeninteresse i å få forhåndsvarsel ikke veier så tungt «at det bør hindre at aksjeeierne seg i mellom kan bli enige om å holde generalforsamling uten at ledelsen blir varslet ...» ${ }^{54}$. Dette standpunktet ble imidlertid ikke gjennomført i loven. I tillegg ble standpunktet i Knudsen-utredningen fraveket i senere lovforarbeider ${ }^{55}$, med blant annet den begrunnelse at muligheten for å gjennomføre forenklet generalforsamling ikke burde kunne «brukes til å avskjære [ledelsen] fra den lovbestemte kontaktflaten mot aksjonærene» ${ }^{56}$. Varsling til ledelsen må derfor anses å være et absolutt vilkår for å kunne avholde forenklet og elektronisk generalforsamling.

Videre følger det av nr. 2 at ledelsen «kan kreve at saken behandles av generalforsamlingen i møte», som etter ordlyden forstås som fysisk møte. Ved krav fra ledelsen om at generalforsamlingen skal avholdes i fysisk form, plikter generalforsamlingen å etterfølge dette selv ved intern enighet om å avholde møte i elektronisk form. $\AA$ «kreve» er et sterkt begrep og en naturlig

\footnotetext{
${ }^{53}$ Prop. 112 L (2016-2017) s. 45 (punkt 5.1.1.4 Departementets vurdering).

${ }^{54}$ Forenkling og modernisering av aksjeloven, en utredning av advokat Gudmund Knudsen, skrevet etter oppdrag fra Justis- og politidepartementet, Oslo, 07.01.2011, s. 123 (punkt 6.3.1.4 Adgang til å fravike lovens krav til generalforsamling ved enighet mellom aksjeeiere).

55 Prop. 111 L (2012-2013) s. 98-99 (punkt 6.2.4 Departementets vurdering) og NOU 2016: 22 s. 96 (punkt 8.2.2.2.3 Nærmere om saksbehandlingsreglene ved forenklet generalforsamling).

${ }^{56}$ NOU 2016: 22 s. 96 (punkt 8.2.2.2.3 Nærmere om saksbehandlingsreglene ved forenklet generalforsamling).
} 
forståelse tilsier derfor at de som kravet retter seg mot - generalforsamlingen - plikter å imøtekomme kravet fra avsenderen - ledelsen. Dette har sammenheng med ledelsens rett til å delta på generalforsamlingen som holdes fysisk, som vil undergraves om ikke ledelsen kan nedlegge «veto» for fysisk møtebehandling. Generalforsamlingen må derfor avholde møte i fysisk form hvor ledelsen «kreve[r]» dette.

Nummer 3 viser at notoritet er en forutsetning for å avholde forenklet elektronisk generalforsamling i form av at det «skal ... føres protokoll, jf. § 5-7 a». Som det følger av § 5-7 a (3), skal protokollen «signeres» av styrelederen eller andre som leder generalforsamlingen. Signeringen kan foregå ved hjelp av elektroniske løsninger, jf. § 1-6 (1). En følge av at forenklet generalforsamling kan gjennomføres uten å følge reglene i §§ 5-8 til 5-16, er at det ikke stilles krav om å benytte en «betryggende metode» for å autentisere undertegneren, sml. § 5-11 b (2) andre punktum. Hvilke autentiserings- og sikkerhetsmekanismer som bør velges av hensyn til sikkerhet, er «en vurdering selskapene er nærmest til å foreta» ${ }^{57}$.

Det vil kunne være en saksbehandlingsfeil å beslutte noe på forenklet generalforsamling hvor pliktene som følger av § 5-7 ikke overholdes. Som det følger av sikker rett, er avgjørende for å kjenne beslutningen ugyldig om feilen har hatt betydning for resultatet. Rene formalitetsfeil vil vanligvis ikke ha slik betydning, eksempelvis hvor protokollen som skal føres i tråd med $\S$ 5-7 a ikke angir at saken er behandlet etter $\S 5-7$. Som det imidlertid påpekes i forarbeidene, kan en slik feil derimot få andre følger, for eksempel medføre at beslutningen vanskeligere lar seg registrere i Foretaksregisteret. ${ }^{58}$

\subsection{Ordinær generalforsamling som gjennomføres fysisk, men hvor én eller flere deltar elektronisk}

\subsubsection{Krav om betryggende måte å kontrollere deltakelse og stemmegivning}

Under ordinær generalforsamling hvor én eller flere aksjonærer deltar elektronisk, stilles det krav om «betryggende måte» å kontrollere deltakelsen og stemmegivningen, jf. § 5-11 b (1) andre punktum. Formålet er å sikre at aksjonærene får mulighet til å utøve sine aksjonærrettigheter, herunder retten til deltakelse, ytring og stemmegivning. I fortsettelsen vil det ses på hvordan sikkerhetskravet ivaretar disse sentrale aksjonærrettighetene etter $\S 5-11$ (1) b andre punktum.

\footnotetext{
${ }^{57}$ NOU 2016: 22 s. 39 (punkt 5.5.4 Utvalgets vurderinger).

${ }^{58}$ ibid. s. 97 (punkt 8.2.2.2.4 Krav til protokoll ved forenklet generalforsamling).
} 
For å forhindre at uvedkommende deltar og stemmer på generalforsamlingen, stiller $\S 5-11 \mathrm{~b}$ (1) andre punktum krav om at deltakelsen må kunne «kontrolleres». Etter vanlig språkforståelse må aksjonærens eller fullmektigens identitet kunne autentiseres. Denne forståelsen samsvarer med det som følger eksplisitt av den tilsvarende bestemmelsen i allmennaksjeloven $\S 5$ 8 (2) siste punktum. Ordlydsforståelsen bekreftes også i Proposisjonen, «[k]ravet til betryggende kontroll innebærer at identiteten til aksjeeieren eller dennes fullmektig må kunne verifiseres» 59 .

Videre stiller ordlyden krav om at kontrollen må foregå på en «betryggende måte». Følgelig må autentiseringsmetoden, etter alminnelig forståelse, være egnet til å sikre at det er rette vedkommende som deltar og stemmer på generalforsamlingen. Systemet som anvendes må kunne registrere hvilke aksjonærer som deltar, antall stemmer og kapitalandel de representerer, i tillegg til å kunne registrere den enkelte deltakers stemmegivning og slå fast det endelige avstemningsresultatet på en pålitelig måte. ${ }^{60}$ For eksempel vil bruk av passord kunne være en praktisk nyttig autentiseringsmetode, spesielt hvor vedkommende må benytte en totrinnsbekreftelse før det gis tilgang til å delta og avlevere stemme. Med «totrinnsbekreftelse» menes et ekstra sikkerhetsnivå for innlogging ved at man bruker noe man selv vet (for eksempel eget passord) i kombinasjon med noe man deretter får (for eksempel kode tilsendt på SMS).

Det kan spørres om selskapenes fleksibilitet i forbindelse med autentiseringskravet strekker så langt at eksempelvis quiz-applikasjonen Kahoot! kan anvendes for å avlevere stemme. «Kahoot!» er en spillbasert læringsplattform som gjør at administratoren på en rask og enkel måte kan lage spørsmål med svaralternativer som registrerte spilldeltakere kan svare på. Applikasjonen er hensiktsmessig og effektiv når det enkelt kan nedfelles spørsmål og relevante svar som «ja», «nei» eller «blank»som må besvares innen en bestemt tid. Hvor mange stemmer hvert enkelt svaralternativ har fått, samt stemmeresultatet, vises og kunngjøres umiddelbart etter stemmegivningen. Kahoot! har også en totrinnsbekreftelse som kan utelukke at uvedkommende deltar og stemmer. I tillegg har administrator adgang til å se hvem som deltar før avstemningen finner sted, men for å identifisere deltakerne, forutsetter det at aksjonærene oppgir navn eller tilsvarende identifikatorer. Videre kan det være en ulempe at det ikke gis anledning til å se hvem som har stemt $h v a$, som gjør at stemmegivningen kun viser et eventuelt flertall etter hoder og ikke etter aksjeinnhav, jf. hovedregelen i aksjeloven § 5-3 (1) første punktum om at «[h]ver aksje gir én stemme når noe annet ikke følger av loven eller vedtektene». Kahoot! fremstår med det å kunne være en sikker ordning i lys av autentiseringskravet, men trolig kun i saker som behøver flertall etter hoder og i selskaper med få aksjonærer som gjør det lett og oversiktlig å bruke applikasjonen.

\footnotetext{
${ }^{59}$ Prop. 112 L (2016-2017) s. 105 (punkt 10.1 Til $\S 5-11$ b).

${ }^{60}$ Aarbakke m.fl. (2017) s. 1083 (note 2.1), jf. s. 383 (note 1.5).
} 


\subsubsection{Styrets rett til å nekte elektronisk deltakelse ved saklig grunn ${ }^{61}$}

En forutsetning for å kunne delta og avgi stemme elektronisk etter § 5-11 b (1), er at styret ikke nekter deltakelsen på «saklig» grunnlag. Etter ordlyden vil det bero på en konkret og helhetlig vurdering om «saklig grunn» foreligger. Ordlydsforståelsen bekreftes i Proposisjonen, hvor det nærmere presiseres at det må tungtveiende grunner til for å nekte aksjonærene deltakelse. ${ }^{62}$ Følgelig legges det opp til en avveining hvor aksjonærens rett til elektronisk deltakelse på generalforsamlingen må vektes mot andre hensyn som alene eller samlet må anses som mer vesentlige. Dette må ses i lys av formålet med saklighetskravet, som, av hensyn til kravet om «betryggende måte», er å nekte deltakelse dersom gjennomføringen ikke kan skje med tilstrekkelig sikkerhet. I fortsettelsen vil det ses nærmere på hva som kan være «saklig» nektelsesgrunnlag.

Aksjeloven $\S 5-11$ b (1) stiller $i k k e$, til forskjell fra allmennaksjeloven $\S 5-8$ a (2) første punktum, eksplisitt krav om at det må foreligge «systemer som sikrer at lovens krav til generalforsamling er oppfylt». En naturlig forståelse av at elektronisk deltakelse forutsetter at gjennomføringen skjer på en «betryggende måte», tilsier derimot at dette også må gjelde etter aksjeloven. Denne tolkningen har støtte i Proposisjonen, hvor det fremgår at styret «skal nekte deltakelse ved hjelp av elektroniske hjelpemidler dersom lovens krav til generalforsamling ikke kan overholdes» ${ }^{63}$. Følgelig kan styret nekte elektronisk deltakelse på «saklig» grunnlag dersom denne forutsetningen ikke foreligger.

Det kan spørres om selskapet har «saklig grunn» til å nekte deltakelse hvor flere ønsker å delta elektronisk på generalforsamlingen. En alminnelig forståelse av at gjennomføringen må foregå på en «betryggende måte», tilsier at styret kan ha «saklig» nektelsesgrunn i selskaper hvor et større antall elektronisk deltakende vil gjøre gjennomføringsmåten betenkelig av hensyn til identifikasjon, spesielt hvor sakene til behandling er av sensitiv art. Dette har støtte i Proposisjonen, hvor det påpekes at selskaper med færre aksjonærer i mindre grad vil kunne «avskjære deltakelse per telefon, Skype eller tilsvarende løsninger, så lenge identiteten til deltakeren er klar. I selskaper med mange aksjeeiere vil en slik form for deltakelse kunne være mer problematisk» ${ }^{64}$. «[S]aklig grunn» til å nekte deltakelse hvor flere ønsker å delta elektronisk på generalforsamlingen kan derfor foreligge etter omstendighetene, spesielt i større selskaper med mange aksjonærer og hvor sakene som er til behandling, er av sensitiv karakter.

\footnotetext{
${ }^{61}$ Temaet er så vidt berørt av Bråthen, Tore, Den norske aksjelovreformen - 1. etappe 2017, Nordisk tidsskrift for Selskapbsret (2017), s. 70-86, se s. 78-79 (punkt 5.2 Deltakelse på generalforsamling ved elektroniske hjelpemidler).

${ }^{62}$ Prop. 112 L (2016-2017) s. 49 (punkt 5.1.3.5 Departementets vurderinger).

${ }^{63} \mathrm{ibid}$.

${ }^{64}$ ibid.
} 
Neste spørsmål er om selskapet kan ha «saklig» nektelsesgrunnlag når det ikke har maskineller programvareløsninger til å støtte elektronisk deltakelse. Dette er noe som må ses i sammenheng med aksjonærenes «rett» til å kunne delta elektronisk på generalforsamlingen, jf. § 5-11 b (1) første punktum. En naturlig forståelse av ordlyden tilsier at selskapet plikter å skaffe nødvendig utstyr i rimelig utstrekning og god tid i forveien før generalforsamlingen skal overholdes for ikke å undergrave aksjonærenes rettighet.

På den annen side presiseres det i Proposisjonen at selskapet vil kunne ha «saklig grunn» til å nekte elektronisk deltakelse hvor det medfører urimelige kostnader å anskaffe det nødvendige kommunikasjonsutstyret «sett hen til selskapets størrelse, aksjeeierstruktur og de kostnader fysisk tilstedeværelse vil påføre aksjeeierne» ${ }^{65}$. Det vil derfor variere etter omstendighetene om manglende maskin- og programvareløsninger kan anses som «saklig» nektelsesgrunn. Terskelen for å anse kostnaden som urimelig må imidlertid være høy i lys av utgangspunktet om aksjonærenes rett til elektronisk deltakelse. Et selskap med negativ egenkapital bestående av tre aksjonærer fra samme familie og som bor i samme nabolag, vil derfor lettere ha «saklig grunn» til å nekte elektronisk deltakelse ved manglende maskin- og programvareløsninger, sammenlignet med et kapitalsterkt aksjeselskap med 50 aksjonærer spredt over hele landet.

Videre vil bekvemmelighetshensyn sett fra selskapets eller majoritetsaksjonærenes side, etter vanlig språkforståelse, ikke kunne være «saklig grunn» til å nekte elektronisk deltakelse. Et eksempel på dette kan være hvor deltakelsen nektes med hensikt om å ekskludere aksjonæren fra generalforsamlingen. En nektelsesgrunn basert på bekvemmelighetshensyn vil også direkte undergrave rettigheten aksjonæren har til elektronisk deltakelse. Videre er det klart forutsatt i Proposisjonen at bekvemmelighetshensyn ikke kan legges til grunn som et «saklig» nektelsesgrunnlag. ${ }^{66}$ Samme sted presiseres det at bekvemmelighetshensyn vil være et vektig moment $\mathrm{i}$ vurderingen om det foreligger misbruk av generalforsamlingens myndighet.

Skulle aksjonærene være uenig i styrevedtaket som nektet vedkommende å delta elektronisk på generalforsamlingen, kan det brukes som grunnlag for søksmål om gyldigheten av generalforsamlingens beslutning etter $\S 5-22 .{ }^{67}$ Dette forutsetter at styrets nektelsesgrunn ikke var «saklig», som igjen har nær sammenheng med kravet til «betryggende måte» etter $§ 5-11 \mathrm{~b}(1)$ andre punktum.

\footnotetext{
${ }^{65}$ Prop. 112 L (2016-2017) s. 49 (punkt 5.1.3.5 Departementets vurderinger).

${ }^{66}$ ibid.

${ }^{67}$ Aarbakke m.fl. (2017) s. 383 (note 1.3).
} 


\subsubsection{Domstolenes adgang til å prøve styrets saklighetsskjønn}

Problemstillingen er i hvilken grad domstolene kan prøve styrets saklighetsskjønn til å nekte elektronisk deltakelse etter $\S 5-11$ b (1) første punktum. Etter ordlyden er det styret, som selskapets forvaltningsorgan, som har kompetansen til å vurdere om «saklig» nektelsesgrunn foreligger eller ikke. Dette tilsier at domstolen, som ikke har den samme nærheten til selskapet, må utvise tilbakeholdenhet ved kontrollen av styrets skjønnsutøvelse.

Det er ingen rettspraksis som direkte angår problemstillingen. I Stangeskovenedommen, som gjaldt prøvelsen av styrets saklighetsskjønn til å nekte samtykke ved aksjeeierskifte etter § 416 (2) første punktum, har Høyesterett imidlertid presisert at «intensiteten i domstolskontrollen vil kunne variere alt etter selskapets karakter og formål og hva som begrunner nektingen ${ }^{68}$. Med tanke på at det er tale om samme skjønnsvilkår - «saklig grunn» - vil dette premisset også kunne sies å gjelde for domstolsprøvingen etter § 5-11 b (1) første punktum. Er det for eksempel tale om en nektelsesgrunn basert på sensitive årsaker, vil domstolen måtte være mer tilbakeholden enn om nektelsesgrunnen baseres på økonomiske hensyn, som kan kvantifiseres.

Videre er det sikker rett at domstolen alltid vil kunne prøve om det foreligger riktig faktum til grunn for skjønnsavgjørelsen, om det er tatt usaklige eller utenforliggende hensyn i begrunnelsen, eller om beslutningen i seg selv er totalt urimelig. I dette ligger blant annet et krav om likebehandling av aksjonærene, jf. asl. § 4-1 (1).

\subsubsection{Betryggende metode å autentisere avsenderen av forhåndsstemme}

Som det følger av § 5-11 b (2) andre punktum, skal det benyttes en «betryggende metode for å autentisere avsenderen» av en forhåndsstemme hvor slik adgang er vedtektsfestet. Etter vanlig språkforståelse må identiteten til avsenderen kunne autentiseres, for eksempel ved en totrinnsbekreftelse. Et eksempel fra praksis er hvordan Equinor ASA krevde totrinnsbekreftelse for avlevering av elektronisk forhåndsstemme til generalforsamlingen av 15. mai 2019, da det krevdes en pinkode $o g$ et referansenummer som stod oppført på skjemaet for påmelding for å avlevere forhåndsstemme. ${ }^{69}$

Det kan stilles spørsmål ved om en elektronisk forhåndsstemme fortsatt skal regnes med eller om aksjonæren må gis anledning til å stemme på nytt dersom dagsordenen etter aksjeloven § 5-14 endres i etterkant. Utgangspunktet følger av bestemmelsens første ledd om at generalforsamlingen bare kan avgjøre saker som «er meddelt aksjeeierne etter reglene om innkalling av generalforsamlingen». Ordlyden tilsier at en elektronisk forhåndsstemme som er basert på innkallingen, ikke kan legges til grunn om den etterfølgende omstendigheten endrer stemmens

\footnotetext{
${ }^{68}$ Rt. 2013 s. 241 avsnitt 49.

${ }^{69} \mathrm{Se}$ https://www.equinor.com/no/what-we-do/calendar/annual-general-meeting-2019.html hentet 03.08.2019.
} 
forutsetning. Dermed legger ordlyden opp til en konkret vurdering av om aksjonærens forutsetning er en annen som følge av endringen. Dette har støtte i juridisk teori, som i tillegg påpeker at det avgjørende må være om forutsetningen endres «vesentlig» ${ }^{70}$. Med tanke på at det er en sentral rettighet for aksjonæren at forhåndsstemmen samsvarer med forutsetningen, må terskelen antas å være lavere enn vesentlighetskravet som forespeiles i juridisk teori. Er forutsetningen endret, må det kunne anses å være nok til å gi aksjonæren anledning til å stemme på nytt.

\subsubsection{Forholdet til vedtektene}

Som det følger av siste punktum i $§ 5-11$ b henholdsvis (1) og (2), kan adgangen til å delta og (forhånds)stemme elektronisk på generalforsamlingen fastsettes nærmere «[i] vedtektene». I fortsettelsen ses det nærmere på forhold som oppstår i forbindelse med adgangen til å vedtektsregulere bruken av elektroniske hjelpemidler på generalforsamlingen.

Det kan spørres om styret kan fastsette nærmere krav til deltakelse og (forhånds)avstemming ved hjelp av elektroniske hjelpemidler hvor styret er fratatt slik kompetanse «[i] vedtektene». En naturlig forståelse tilsier at styret må respektere generalforsamlingen som øverste myndighet og dennes kompetanse til å vedtektsregulere kommunikasjonsmåten. Ordlyden taler dermed for at styret ikke kan fastsette nærmere krav til elektronisk deltakelse mv. på generalforsamlingen hvor dette allerede er fastsatt «[i] vedtektene».

På den annen side kan det være utfordrende for selskapene å overholde sin plikt til å tilrettelegge for elektronisk deltakelse og stemmegivning, «uten å vite på forhånd hvilke aksjeeiere som ønsker å benytte seg av denne retten» ${ }^{71}$. Proposisjonen taler dermed for at styret må ha adgang til å kunne sette nærmere krav til praktiske forhold knyttet til deltakelsen uten hjemmel «[i] vedtektene», slik at deres plikt til å legge til rette for en «betryggende» gjennomføringsmåte kan gjøres forsvarlig. Det trekkes frem som et eksempel at styret kan bestemme at aksjonærene «må melde fra om de ønsker å delta på generalforsamlingen ved hjelp av elektroniske hjelpemidler i rimelig tid før møtetidspunktet» ${ }^{72}$. Dette er også fremhevet i juridisk teori. ${ }^{73}$ Styret må derfor, av hensyn til en forsvarlig utøvelse av sine plikter, kunne sette krav om praktiske forhold i forbindelse med elektronisk deltakelse selv hvor generalforsamlingen har fratatt kompetansen «[i] vedtektene».

\footnotetext{
${ }^{70}$ Aarbakke m.fl. (2017) s. 1085 (note 0.4), jf. s. 384 (note 2.1).

${ }^{71}$ Prop. 112 L (2016-2017) s. 50 (punkt 5.1.3.5 Departementets vurderinger).

72 ibid.

${ }^{73}$ Aarbakke m.fl. (2017) s. 383 (note 1.6).
} 
Videre kan ikke generalforsamlingen «[i] vedtektene» fravike eller lempe kravet om at gjennomføringen skal skje på en «betryggende måte». Hele forutsetningen for bruk av elektroniske løsninger i forbindelse med selskapskommunikasjon bygger på at informasjon kommer til mottakerens kunnskap på tilstrekkelig sikkert vis. Dette gjelder med tyngde på generalforsamlingen, hvor det er tale om å utøve aksjonærrettigheter i praksis. Grunnforutsetningen har støtte i juridisk teori, hvor det fremgår at man ikke kan lempe på sikkerhetskravet i § 5-11 b (1) annet punktum. ${ }^{74}$ En følge av dette er at kravet til «saklig grunn» etter første punktum heller ikke kan begrenses eller fravikes «[i] vedtektene», ettersom saklighetskravet har nær sammenheng med kravet til «betryggende måte».

Det kan vanskelig ses å foreligge forhold som gjør at sikkerhetskravet ikke kan gjøres strengere «[i] vedtektene». Om så gjøres, må det ligge innenfor rammen av myndighetsmisbruksregelen i aksjeloven § 5-21. Dette innebærer blant annet at det kan være myndighetsmisbruk å sette krav som gjør at enkelte deltakere ikke har mulighet til å kunne delta, uttale seg eller stemme på generalforsamlingen.

\subsection{Teknologisk svikt under generalforsamlingen}

Bruk av elektroniske hjelpemidler ved gjennomførelse av generalforsamlingen er ikke uproblematisk. Det kan være maskin- og programvaren ikke fungerer optimalt, som igjen kan medføre at aksjonærens muntlige uttalelser henger etter, skurrer eller gjøres stum, eller at skriftlige meldinger ikke mottas. Videre kan det oppstå systembrudd som gjør at aksjonæren ikke får deltatt fra starten av eller faller ut underveis og derved ikke får avlevert stemme, eventuelt om forhåndsstemmen ikke registreres. I fortsettelsen vil det ses på hvilke plikter og konsekvenser som oppstår når generalforsamlingen opplever teknologisk svikt.

Generalforsamlingen vil ha en plikt til å fikse og eventuelt stoppe behandlingen hvor kravet til «betryggende» og «egnet» måte ikke kan overholdes som følge av teknologisk svikt, jf. henholdsvis $\S \S 5-11$ b (1) andre punktum og 5-7 nr. 1. En naturlig forståelse tilsier at det ikke er «betryggende» eller «egnet» å fortsette hvor aksjonærene grunnet teknologiske problemer faller ut, ikke får uttale seg eller avlevert stemme. Av hensyn til at dette er sentrale aksjonærrettigheter, må generalforsamlingen sies å ha en vid plikt til å fikse eventuelle problemer som oppstår.

Videre er det ikke naturlig å forstå ordlyden slik at enhver svikt gjør at behandlingen ikke kan fortsette. Dette har støtte i juridisk teori i tilknytning til gjennomføringen av generalforsamlingen etter allmennaksjeloven $\S 5$-8 a, som har relevans for gjennomføringen etter aksjeloven

\footnotetext{
${ }^{74}$ Aarbakke m.fl. (2017) s. 384 (note 1.6).
} 
§ 5-11 b. Her presiseres det at møtelederen må foreta en konkret vurdering «om det skal tas pause i forhandlingene eller utsette generalforsamlingen til feilen er rettet» ${ }^{75}$. Det presiseres også at vurderingen beror på hva svikten «har å si for behandlingen av sakene som er satt på dagsordenen, og utøvelsen av aksjeeiernes rettigheter på generalforsamlingen» ${ }^{76}$. Feilens karakter vil derfor være et sentralt moment. Generalforsamlingen vil lettere kunne fortsette hvor det er tale om en svak skurring enn ved «mer varige brudd som helt avskjærer de som har basert seg på elektronisk deltakelse fra å delta» ${ }^{77}$. I tillegg vil generalforsamlingen i større grad kunne fortsette hvor feilen skyldes forhold på aksjonærens side, eksempelvis feil med aksjonærens maskinvare. Dette må også sies å gjelde situasjoner hvor aksjonæren har satt seg selv i en posisjon som vanskeliggjør elektronisk deltakelse, for eksempel å være på hytta med svak internettforbindelse.

Teknologisk feil kan påvirke beslutningene som treffes på generalforsamlingen, for eksempel hvor en avgjørende stemme ikke blir registrert eller en viktig uttalelse ikke ble hørt på grunn av kraftig skurring. Aksjonæren som deltar elektronisk og som opplever teknologisk svikt, vil derfor kunne bruke dette som grunnlag til å reise søksmål med påstand om å kjenne generalforsamlingsbeslutningen ugyldig så langt ugyldighetsgrunnen rekker, jf. § 5-22.

For å kunne kjenne generalforsamlingens beslutning ugyldig, setter § 5-22 første punktum krav om at den må ha blitt til på «ulovlig måte eller for øvrig er i strid med loven eller selskapets vedtekter». Etter ordlyden vil brudd på aksjelovens bestemmelser i forbindelse med deltakelse på elektronisk generalforsamlingen kunne brukes som ugyldighetsgrunnlag. Et eksempel på dette er hvor det ikke var «betryggende» å fortsette generalforsamlingen på grunn av elektroniske problemer, jf. § 5-11 b (1) andre punktum. Et annet eksempel er hvor aksjonærene som deltok fysisk misbrukte sin posisjon overfor de som deltok elektronisk i strid med myndighetsmisbruksregelen i § 5-21. Dette kan for eksempel være sjikanøs atferd hvor man bevisst unnlater å fikse problemene som oppstår eller kobler av deltakerne med hensikt.

\footnotetext{
${ }^{75}$ Aarbakke m.fl. (2017) s. 1083 (note 2.2).

${ }^{76} \mathrm{ibid}$.

${ }^{77}$ ibid.
} 


\section{$6 \quad$ Bruk av elektroniske hjelpemidler i styret}

\subsection{Innledning}

For at styret skal kunne overholde sitt formål om å forvalte selskapets anliggender og sørge for en operativ drift, må styremedlemmene kunne kommunisere effektivt seg imellom. Styret skal derfor behandle saker i «møte ... eller på annen ... måte», herunder elektronisk, jf. asl. § 6-19 (1). Selv om ordlyden kan tyde på at fysiske møter er hovedregelen, er det likevel klart forutsatt i forarbeidene og juridisk teori at styret har en høy grad av frihet til å bestemme sin arbeidsform. ${ }^{78}$ I alle tilfeller er det uansett krav etter $\S 6-19$ (1) at behandlingsformen må være «betryggende», noe fysisk møteform forutsettes å være. Det drøftes under punkt 6.2 hva som menes med «betryggende måte» i styresammenheng. Under punkt 6.3 vil det redegjøres for hvilke plikter som oppstår ved teknologisk svikt under styrebehandlingen.

\subsection{Krav om betryggende styrebehandlingsform}

Med mindre styremedlemmene og daglig leder krever møtebehandling, jf. § 6-19 (2) siste punktum, er det etter første ledd styrelederen som i utgangspunktet bestemmer om det er «betryggende» å gjennomføre et styremøte elektronisk. I beslutningen om andre former enn fysisk møte er «betryggende», må det foretas en konkret og skjønnsmessig vurdering hvor hensynet til sikker behandlingsform må balanseres mot behovet for en høy grad av fleksibilitet. ${ }^{79}$

At styrebehandlingen kan gjennomføres «skriftlig» etter § 6-19 (1), innebærer etter vanlig språkforståelse at møtet kan gjennomføres over digitale medier som muliggjør elektronisk skriftkommunikasjon. Et eksempel på dette er «sirkulasjon av dokumenter» ${ }^{80}$ over e-post. Når ordlyden videre åpner opp for styrebehandling «på annen måte», er det naturlig å forstå dette som en adgang til å benytte andre elektroniske kommunikasjonsmåter enn skriftlige, typisk muntlig gjennomførelse over telefon eller Skype.

Terskelen for hva som vil være «betryggende måte» vil kunne variere alt ettersom styrebehandlingen foregår synkront eller asynkront. Som det følger av § 6-19 (2) første punktum, skal styrets leder «sørge for at styremedlemmene så vidt mulig kan delta i en samlet behandling av saker som behandles uten møte». En alminnelig forståelse tilsier at synkrone kommunikasjonsmåter lettere vil kunne være «betryggende» enn ved asynkrone behandlingsformer, ettersom

\footnotetext{
${ }^{78}$ Prop. 111 L (2012-2013) s. 105 (punkt 6.5.4 Departementets vurdering) og Aarbakke m.fl. (2017) s. 530 (note 1.1).

${ }^{79}$ Prop. 111 L (2012-2013) s. 104 (punkt 6.5.4 Departementets vurdering).

${ }^{80}$ NOU 1996: 3 s. 143 (punkt 13.5.2 IV Til § 5-26 [Lovens § 6-19]).
} 


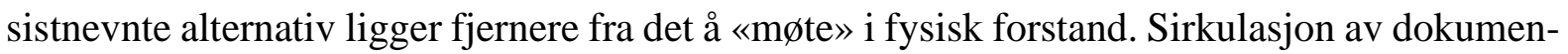
ter bør derfor «bare benyttes i helt kurante saker» ${ }^{81}$, typisk i saker av mindre viktig karakter.

Videre stiller ikke aksjeloven § 6-19 (1), til forskjell fra allmennaksjeloven § 6-19 (1) andre til fjerde punktum, krav om at saker som angår årsregnskap, årsberetning, lønn til daglig leder og andre ledende ansatte, må behandles og vedtas i fysisk møte. Dette ble endret i aksjeloven allerede ved lov 14. juni 2013 nr. 40 om endringer i aksjelovgivningen mv. (forenklinger). Likevel er slike saker av svært viktig karakter, noe som ble understreket i forarbeidene ved at man «under noe tvil» ${ }^{82}$ foreslo å følge opp forslaget i utredningen om å oppheve kravet til fysisk møteform i slike saker. Terskelen for å betrakte elektroniske gjennomføringsmåter som «betryggende» må derfor anses å være høy hvor sakene som står på agendaen, gjelder årsregnskap mv. Følgelig kan det vanskelig sies å være kurant å benytte asynkrone kommunikasjonsmåter i slike saker.

Det er ikke en forutsetning for at det skal være tale om en «betryggende» gjennomføringsmåte at styremedlemmene deltar på samme kommunikasjonsplattform, for eksempel utelukkende ved hjelp av Skype. Gjennomføringsmåten vil fortsatt kunne betraktes som «betryggende» så lenge samtlige styremedlemmer, uavhengig av det elektroniske hjelpemiddelet som benyttes, får mulighet til å delta, uttale seg og stemme. Det følger også av juridisk teori at ulike kommunikasjonsmåter må kunne benyttes. ${ }^{83}$

Dersom styreleder ser den elektroniske gjennomføringsmåten som «betryggende» og beslutter å gjennomføre styremøtet slik, skal saken forberedes og fremlegges på en måte som gir styret et «tilfredsstillende behandlingsgrunnlag», jf. asl. § 6-21 (2). Hva som vil være et «tilfredsstillende behandlingsgrunnlag» vil etter ordlyden bero på en konkret vurdering. Dette presiseres i forarbeidene, hvor det fremgår at «[h]vilke krav som skal stilles til omfanget og dybden av dokumentasjonen må avpasses etter sakens karakter» ${ }^{84}$. For eksempel må det stilles høyere krav til behandlingsgrunnlaget hvor saken som skal gjennomføres på elektronisk måte, er årsregnskapet og årsberetningen, enn om selskapet skal vurdere tilbudet om å bli fast bedriftskunde av en kaffeleverandør. «[T]idspress» ${ }^{85}$ må også kunne trekkes inn i vurderingen av hvilke krav som stilles. Terskelen kan dermed være lavere $\mathrm{i}$ hastesaker enn i saker som har vært planlagt over lengre tid.

\footnotetext{
${ }^{81}$ Aarbakke m.fl. (2017) s. 531 (note 1.1).

${ }^{82}$ Prop. 111 L (2012-2013) s. 104 (punkt 6.5.4 Departementets vurdering).

${ }^{83}$ Aarbakke m.fl. (2017) s. 531 (note 1.1).

${ }^{84}$ NOU 1996: 3 s. 144 (punkt 13.5.2 IV Til § 5-28 [Lovens § 6-21]).

${ }^{85}$ ibid.
} 
Videre fremheves det i juridisk teori at kravet til betryggende behandling innebærer «større krav til saksdokumentasjonen når en styresak behandles uten møte enn når møteform benyttes, og styremedlemmene kan få supplerende informasjon umiddelbart fra daglig leder eller andre representanter fra administrasjonen ${ }^{86}$. Fraværet av umiddelbarhet tilsier derfor at synkrone løsninger, som telefon- og videokonferanser, stiller lavere krav til behandlingsgrunnlaget enn asynkrone gjennomføringsmåter, for eksempel dokumentsirkulasjon på e-post. Umiddelbarhetshensyn vil dermed også kunne trekkes inn i vurdering av hvilke krav som stilles til behandlingsgrunnlaget.

\subsection{Teknologisk svikt under styrebehandlingen}

I likhet som på generalforsamlingen vil det ofte ikke kunne være «betryggende» å fortsette et styremøte hvor det oppstår teknologiske problemer, for eksempel hvor styremedlemmer faller ut, ikke får uttale seg eller avgitt stemme. En naturlig forståelse av at gjennomføringsmåten skal være «betryggende», jf. § 6-19 (1), tilsier at styret har en vid plikt til å fikse problemene som oppstår og at møtet eventuelt må stoppe om ikke problemene kan løses. Dette har sammenheng med styremedlemmenes rett og plikt til å kunne delta på styremøtet og at styremedlemmene kan bli erstatningsansvarlige ved brudd på denne plikten, jf. asl. § 17-1 (1). Videre kan det for selskapet og aksjonærene være av betydning at styremedlemmene som deltar på styrebehandlingen får mulighet til å uttale seg og stemme, slik at beslutningen får et representativt og bredt grunnlag.

I aksjeloven § 6-24 (1) stilles det imidlertid krav om at styret må være beslutningsdyktig for å kunne «treffe beslutning», som normalt er når mer enn halvparten av medlemmene er til stede eller deltar i styrebehandlingen. Dette kan tyde på at styret ikke har plikt til å fikse eventuelle teknologiske problemer som oppstår eller å stoppe et møte så lenge det til enhver tid er beslutningsdyktig. Retten, plikten og ansvaret som styremedlemmene har til å delta på styremøter må likevel kunne sies å veie tyngst. Styret vil derfor ha plikt til å fikse teknologiske problemer som skulle oppstå underveis og en eventuell plikt til å stoppe behandlingen selv hvor det fortsatt er beslutningsdyktig. I likhet som på generalforsamlingen, vil feilens karakter og forhold på styremedlemmets side være relevante momenter i vurderingen av om behandlingen skal fortsette eller ikke.

Skulle ikke styret få gjenkontakt med styremedlemmet som faller ut på grunn av teknologiske problemer, er spørsmålet om «betryggende» gjennomføringsmåte gir plikt til å forsøke å kontakte eventuelle varamedlemmer ved hjelp av telefon eller andre elektroniske hjelpemidler. Etter ordlyden kan det vanskelig sies å ha vært tale om en «betryggende» gjennomføringsmåte

\footnotetext{
${ }^{86}$ Aarbakke m.fl. (2017) s. 531 (note 1.2).
} 
hvor styret ikke har forsøkt å kontakte eventuelle varamedlemmer som erstattere. Dette har støtte i formålet med varaordningen som nettopp er å erstatte styremedlemmer som ikke lenger får delta.

Videre følger det av aksjeloven § 6-24 (3) at styret plikter å innkalle eventuelle varamedlemmer hvor styremedlemmene har «forfall». En naturlig forståelse tilsier at det foreligger et «forfall» hvor styremedlemmet uønsket faller ut som følge av teknologiske årsaker og ikke får gjenkontakt. Dermed taler også § 6-24 (3) for at styret plikter å kontakte eventuelle varamedlemmer hvor styremedlemmer faller ut.

På den annen side argumenteres det i juridisk teori for at styret ikke har plikt til å varsle eventuelle varamedlemmer «som ikke oppholder seg i nærheten av møtestedet» ${ }^{87}$. Dette kan imidlertid ikke tillegges avgjørende vekt når dagens teknologi ikke krever umiddelbar fysisk nærhet. Eventuelle varamedlemmer kan enkelt kontaktes og delta ved hjelp av elektroniske hjelpemidler, som oftest uavhengig av lokalisasjon. Følgelig må det anses å foreligge en plikt for styret til å fors $\emptyset$ ke å nå eventuelle varamedlemmer elektronisk dersom styremedlemmet faller ut som følge av tekniske feil.

${ }^{87}$ Aarbakke m.fl. (2017) s. 541 (note 3.1). 


\section{$7 \quad$ Oppbevaring av og innsyn i selskapsdokumentasjon}

\subsection{Innledning}

Aksjeloven § 1-6 (1) regulerer elektronisk oppbevaring av selskapsdokumentasjon. Hvor selskapsaktørene får innsyn i «[d]okumentasjon som kreves utarbeidet etter aksjeloven», jf. første punktum, er det tale om proaktiv kommunikasjon. Under punkt 7.2 drøftes hva som kan være slik «[d]okumentasjon». Videre følger det at dokumentasjonen skal oppbevares på en «betryggende måte». Dette reiser ulike problemstillinger som drøftes under punkt 7.3. Ved siden av kravet til «betryggende måte» er det vilkår i andre punktum om at dokumentene må være i «lesbar form» og «tilgjengelig fra Norge», som redegjøres for under punktene 7.4 og 7.5.

\subsection{Dokumentasjon som kreves utarbeidet etter aksjeloven}

Det er «[d]okumentasjon som kreves utarbeidet etter aksjeloven» som er gjenstand for dokumentasjonsplikt og som det kan kreves innsyn i. Etter ordlyden er det naturlig å forstå at oppbevaringsplikten gjelder for enhver selskapsinformasjon som må opprettes etter aksjelovens regler. Dette kan for eksempel være opplysninger i aksjeeierboken, som, med unntak av «aksjeeiernes digitale adresse», «skal være tilgjengelige for enhver», jf. asl. § 4-6 første og andre punktum. Som videre eksempler nevnes i Proposisjonen «stiftelsesdokumenter, generalforsamlingsprotokoller og styreprotokoller ${ }^{88}$.

Det kan spørres om dokumentasjon etter § 1-6 (1) bare omfatter dokumenter som selskapet utarbeider eller om også meldinger mv. fra aksjonærene til selskapet omfattes. Ordlyden synes å omfatte meldinger mv. fra aksjonærene til selskapet, så lenge det kreves «utarbeidet etter aksjeloven». Dette kan for eksempel være meldinger om aksjeerverv som «skal» sendes til selskapet, jf. § 4-12, melding om å gjøre forkjøpsretten gjeldende, jf. § 4-23 (1) første punktum, eller melding om å benytte retten til å få bestemte saker behandlet på generalforsamlingen, jf. § 5-11 første og andre punktum.

I Proposisjonen fremkommer det derimot «at ikke all dokumentasjon som kreves utarbeidet etter aksjeloven» ${ }^{89}$ skal anses som selskapsdokumentasjon etter § 1-6 (1). Dermed utelukker ikke forarbeidene at meldinger mv. fra aksjonærene til selskapet kan falle utenfor dokumentasjonsplikten. Det presiseres imidlertid ikke at slike meldinger mv. faller utenfor og uttalelsene i Proposisjonen kan derfor vanskelig tillegges vekt.

\footnotetext{
${ }^{88}$ Prop. 112 L (2016-2017) s. 21 (punkt 4.1.5.1 Legaldefinisjon av selskapsdokumentasjon).

${ }^{89}$ ibid.
} 
Klarere er Bråthen og Minde, som uten videre påpeker at selskapsdokumentasjonen «neppe [omfatter] annen dokumentasjon enn den som utarbeides av selskapet» ${ }^{90}$. Dette synspunktet er imidlertid ikke gjennomgående i litteraturen. Aarbakke m.fl. mener at det er tvilsomt om $§ 1-$ 6 (1) omfatter meldinger mv. fra aksjonærene til selskapet som kreves utarbeidet etter aksjeloven og at plikten til betryggende oppbevaring kan «tenkes å gjelde for selskapet når det mottar slike dokumenter» ${ }^{91}$. Manglende ensartethet i relevant litteratur gjør derfor at det som følger av juridisk teori ikke kan tillegges vekt.

Hensynet til notoritet kan derimot tale for at meldinger mv. fra aksjonærene til selskapet som kreves utarbeidet etter aksjeloven, omfattes. For eksempel kan notoritet være praktisk med tanke på utøvelse av forkjøpsrett. Ved å dokumentere når selskapet fikk meldingen om eierskifte og melding om å gjøre forkjøpsretten gjeldende, vil man enkelt kunne regne ut om forkjøpsretten er foreldet etter aksjeloven § 4-23 (1).

Etter dette er det nærliggende å si at meldinger mv. fra aksjonærene til selskapet som kreves «utarbeidet etter aksjeloven», omfattes av § 1-6 (1). Samtidig kan det påpekes at oppbevaringsplikten gjelder selskapet og ikke aksjonærene, som følger av at selskapet er ansvarlig for selskapsforvaltningen etter $\S 6-12 \ll$ og derved for at reglene i [\$ 1-6] overholdes» ${ }^{92}$.

\subsection{Krav om betryggende oppbevaringsmåte}

Kravet til «betryggende» oppbevaringsmåte innebærer krav om å sikre at informasjonen ikke urettmessig går tapt, ødelegges eller endres. Dette kan sies å følge av en alminnelig forståelse av ordlyden, ettersom oppbevaring vanskelig kan anses «betryggende» dersom uberettigede kan fjerne eller manipulere informasjonen. Ordlyden har støtte i Proposisjonen, hvor det nærmere presiseres at «[1]øsningen må gi en forholdsmessig sikkerhet mot endring, ødeleggelse og tap ${ }^{93}$ av hensyn til verdien selskapsdokumentasjonen kan ha. I vurderingen av om den valgte løsningen er forholdsmessig og følgelig «betryggende» satt opp mot risikoen for endringer mv., vil selskapenes individuelle forhold og dokumentets karakter og innhold få betydning. For eksempel vil det stilles høyere krav til sikkerhet ved oppbevaring av sensitiv selskapsinformasjon, enn informasjon av ikke-sensitiv art.

\footnotetext{
${ }^{90}$ Bråthen, Tore og Stine Winger Minde, Nye norske regler om utarbeidelse og oppbevaring av selskapsdokumentasjon og kommunikasjon mellom aksjonarer og aksjeselskap, Nordisk tidsskrift for Selskabsret (2017), s. 104-115, se s. 107 (punkt 3.2 Hva slags dokumentasjon er omfattet av regelen om utarbeidelse og oppbevaring av dokumentasjon?).

${ }^{91}$ Aarbakke m.fl. (2017) s. 103 (note 1.1).

${ }^{92}$ Prop. 112 L (2016-2017) s. 103 (punkt 10.1 Til § 1-6).

${ }^{93}$ ibid. s. 23 (punkt 4.1.5.2 Utarbeidelsesmåte og oppbevaringsmedium).
} 
Videre kan det spørres om kravet til «betryggende» elektronisk oppbevaringsmåte innebærer et krav om å sikkerhetskopiere dokumentasjonen, det vil si at det sørges for at det finnes to eksemplarer av et dokument. En naturlig forståelse tilsier at det ikke er et nødvendig krav for å oppbevare dokumentet på en «betryggende måte» at det er sikkerhetskopiert, men at det kan være nødvendig etter en konkret og skjønnsmessig vurdering. For eksempel vil det vanskelig være tale om en «betryggende» oppbevaringsmåte dersom selskapet ikke sikkerhetskopierer et dokument som kan innebære rettsvirkninger, sammenlignet med situasjonen hvor dokumentet er av mindre viktig karakter.

På den annen side fremgår det i Proposisjonen at det «må ... foretas sikkerhetskopiering» ${ }^{94}$ før oppbevaringen kan sies å være «betryggende». Forarbeidene taler dermed for at sikkerhetskopiering er en absolutt sikkerhetsforutsetning. Et like direkte krav står imidlertid ikke i aksjeloven § 1-6 (1) første punktum. Av hensyn til målsetningen om å skape et lovverk som brukerne enkelt kunne innrette seg etter, kan Proposisjonen vanskelig tillegges avgjørende vekt.

I tillegg er Proposisjonen kritisert i juridisk teori på dette punkt. Essensen i kritikken er at det anses usikkert om kravet til sikkerhetskopiering også gjelder for papirdokumentasjon. Det vil stride med teknologinøytralitet om dette besvares benektende, mens et bekreftende svar innebærer en skjerpelse som vanskelig kan tenkes berettiget med hjemmel i forarbeidene. ${ }^{95}$ Følgelig kan det ikke sies å foreligge noe absolutt krav til sikkerhetskopiering for å anse oppbevaringsmåten som «betryggende» etter aksjeloven $\S 1-6$ (1).

Det gjelder ikke krav om sikkerhetsrutiner for å kunne betrakte oppbevaringsmåten som «betryggende». Noe slikt krav følger ikke direkte av § 1-6 (1). Videre ble ikke forslaget i Proposisjonen om å stille generelle krav til oppbevaring om hva som kan være «betryggende måte», herunder krav om oppbevaringsrutiner, fulgt opp i lovteksten. ${ }^{96}$ Hensynet til notoritet tilsier derimot at selskapet som kan vise til gode oppbevaringsrutiner, lettere vil kunne sies å ha oppbevart dokumentene på en «betryggende måte».

Videre kreves det ikke, for å få tilgang til innsyn i dokumentene, passord for å anse oppbevaringsmåten som «betryggende». Det ligger i ordlyden at det beror på en individuell og skjønnsmessig vurdering av om manglende bruk av passord bryter med kravet til «betryggende» oppbevaringsmåte. For eksempel vil det ikke være tale om en «betryggende» oppbevaringsmåte

\footnotetext{
94 Prop. 112 L (2016-2017) s. 23 (punkt 4.1.5.2 Utarbeidelsesmåte og oppbevaringsmedium).

${ }^{95}$ Bråthen og Minde (2017) s. 109 (punkt 3.3 Utarbeidelse og oppbevaringsmåte).

${ }^{96}$ Prop. 112 L (2016-2017) s. 23 (punkt 4.1.5.4 Oppbevaringssted for selskapsdokumentasjon).
} 
hvor bedriftshemmeligheter oppbevares uten passord og samtidig gjøres tilgjengelig for offentligheten, enn hvor det ikke er tale om sensitiv informasjon.

Det gjelder derimot krav om gjenfinnbarhet for å anse kravet til «betryggende» oppbevaringsmåte som oppfylt. Dette må anses å følge av en naturlig ordlydsforståelse, ettersom det vanskelig kan sies å være tale om en «betryggende» oppbevaringsmåte hvor selskapet ikke finner igjen det aktuelle dokumentet. Ordlyden har støtte i Proposisjonen, hvor det påpekes at kravet skal ivareta «behovet for notoritet, aktørenes mulighet til signering på hensiktsmessig måte og videreformidling av dokumentasjon» ${ }^{97}$. Dette er forhold som nettopp vanskelig kan ivaretas eller la seg gjennomføre med mindre dokumentet kan gjenfinnes. I juridisk teori anbefales det derfor at dokumenter av et visst omfang bør være i et «ordnet system som sikrer at det er mulig å gjenfinne et bestemt dokument eller en bestemt fil uten betydelige anstrengelser» ${ }^{98}$.

\subsection{Krav om lesbarhet}

Dokumentene skal lagres $\mathrm{i}$ «lesbar form», som etter ordlyden betyr at dokumentet må kunne leses på samme måte som tradisjonelle skriftdokumenter. Dette vil gjøre en eventuell «behandling og gjennomgåelse av dokumentasjonen enklere» ${ }^{99}$, for eksempel hvor det gjennomføres gransking. Videre presiseres det i Proposisjonen at formater som lyd- og videoopptak ikke vil oppfylle kravet, herunder må lagringsformatene for elektronisk lagrede dokumenter «oppdateres og eventuelt konverteres for å sikre at dokumentene kan leses» ${ }^{100}$. Ordlyden utelukker imidlertid ikke adgangen til å oppbevare dokumentene på annet format, så lenge dette gjøres som et tillegg.

Ved siden av lesbarhetskravet kan det ikke innfortolkes et krav om at oppbevaringen må kunne skrives ut på papir i hele oppbevaringsperioden. Det fremgår ikke som et eksplisitt krav i § 16 (1) andre punktum. I Proposisjonen delte man også Utvalgets syn om at det ikke skulle stilles krav om at selskapsdokumentasjonen måtte kunne skrives ut, med den begrunnelse at det kunne medføre «uhensiktsmessige hindringer for valg av format i fremtiden» ${ }^{101}$.

\subsection{Krav om tilgjengelighet fra Norge}

At dokumentasjonen skal være «tilgjengelig fra Norge» betyr ikke at det må oppbevares i Norge. Etter ordlyden kan dokumentasjonen sies å være «tilgjengelig fra Norge» når den som krever innsyn, er i Norge og samtidig har eller kan få tilgang til dokumentasjonen. Dette tilsier

\footnotetext{
${ }^{97}$ Prop. 112 L (2016-2017) s. 103 (punkt 10.1 Til § 1-6).

98 Aarbakke m.fl. (2017) s. 103-104 (note 1.3).

${ }^{99}$ Prop. 112 L (2016-2017) s. 22 (punkt 4.1.5.2 Utarbeidelsesmåte og oppbevaringsmedium).

100 ibid.

101 ibid.
} 
at dokumentene må kunne lagres på en harddisk utenfor Norge, eller en nettsky hvor serveren oppbevares utenfor Norge, såfremt informasjonen er eller kan gjøres «tilgjengelig fra Norge».

Ordlyden har støtte i forarbeidene. I Proposisjonen påpekes det at dokumentasjonen må være eller gjøres tilgjengelig fra Norge ved innsynsforespørsel og at styret utover dette selv bestemmer oppbevaringssted. ${ }^{102}$ Videre fremhever Utvalget at det «bør være opp til selskapene å avgjøre hvor selskapsdokumentasjonen skal oppbevares» ${ }^{103}$. Dermed er det lagt tung vekt på selskapenes behov for fleksibilitet.

I juridisk teori gis det derimot uttrykk for at tilgjengelighetskravet «antakelig [innebærer] at dokumentene må lagres på en harddisk i Norge» ${ }^{104}$. Bakgrunnen hviler på formålet med tilgjengelighetskravet om å lette en eventuell gjennomgang av selskapsdokumentasjonen ved konkurs eller lignende. Som det følger av Proposisjonen, vil et selskapsdokument som befinner seg «på en harddisk utenfor Norge og [samtidig] ikke er tilgjengelig fra Norge» ${ }^{105}$, kunne by på betydelige tilgangsvanskeligheter. For å lette en eventuell kontroll- og tilsynsprosess, kan det tilsi at dokumentene må lagres på en harddisk i Norge for å anses å være «tilgengelig fra Norge». Selv om dette kan ha gode grunner for seg, må ordlyden og forarbeidene likevel kunne tillegges tyngst vekt veid opp mot antakelser i juridisk teori. Dokumentene må derfor kunne oppbevares uavhengig av sted så lenge det er eller gjøres «tilgjengelig fra Norge» ved forespørsel om innsyn.

\footnotetext{
${ }^{102}$ Prop. 112 L (2016-2017) s. 103 (punkt 10.1 Til § 1-6).

${ }^{103}$ NOU 2016: 22 s. 42 (punkt 5.6.3.3 Oppbevaringssted)

${ }^{104}$ Aarbakke m.fl. (2017) s. 103 (note 1.3).

${ }^{105}$ Prop. 112 L (2016-2017) s. 27 (punkt 4.5.1.9 Oppbevaringssted).
} 


\section{$8 \quad$ Oppsummering}

Gjennomgangen har vist at kravet til «betryggende måte» $\mathrm{i}$ forbindelse med ekommunikasjon i aksjeselskapsforhold som oftest legger opp til en konkret og skjønnsmessig vurdering. I vurderingen må selskapsaktørenes rettigheter og plikter avveies mot behovet selskapet har for fleksibilitet og effektivitet. Vekten av de ulike hensynene vil blant annet variere fra selskap til selskap og etter innholdet og karakteren av det som kommuniseres. Notoritet står også sentralt.

Ved kommunikasjon fra selskapet til aksjonærene har selskapet en vid rett til å bestemme kommunikasjonsmåten, men må forholde seg innenfor kravet til «betryggende og hensiktsmessig måte». Dette må også generalforsamlingen ved utøvelse av sin instruksjonsrett. Kravene som settes til sikkerhet må ligge innenfor rammen av myndighetsmisbruksreglene, som er tilfellet når kommunikasjonsmåten er «betryggende og hensiktsmessig». Meldinger mv. til aksjonærens oppgitte digitaladresse i aksjeeierboken presumeres å oppfylle sikkerhetskravet. I tillegg har selskapet en vid aktivitetsplikt, men kan ikke kommunisere via aksjonærens nærstående.

Ved meldinger mv. fra aksjonærene til selskapet vil ekommunikasjon til selskapets oppgitte digitaladresser være en «betryggende og hensiktsmessig måte» å kommunisere på. Kravet innebærer at selskapet har en vid plikt til å akseptere også meldinger mv. som ikke sendes til selskapets oppgitte digitale adresse. Selskapet plikter videre å akseptere meldinger mv. sendt fra andre digitaladresser enn aksjonærens når det anses å være sendt på en «betryggende og hensiktsmessig måte», typisk fra aksjonærens nærstående.

På generalforsamlingen stilles det strenge krav til sikkerhet av hensyn til aksjonærenes grunnleggende rettigheter til å delta, uttale seg og avgi stemme. Videre medfører kravet til «betryggende måte» en vid plikt til å ordne opp i teknologiske problemer som skulle oppstå og en eventuell plikt til å stoppe og utsette generalforsamlingen hvor problemene ikke kan løses. Dette gjelder også ved forenklet gjennomførelse, som i denne forbindelse ikke kan brukes til å undergrave aksjonærenes grunnleggende rettigheter.

Styret har stor fleksibilitet i bruken av ekommunikasjon. Kravet til «betryggende måte» gir også styret en vid plikt til å ordne opp i teknologiske problemer som finner sted og en eventuell plikt til å stoppe behandlingen. I tillegg medfører sikkerhetskravet at styret plikter å fors $\varnothing \mathrm{ke} a ̊$ nå eventuelle varamedlemmer elektronisk dersom styremedlemmer faller ut.

Kravet til «betryggende måte» gjør at oppbevarte selskapsdokumenter skal sikres mot urettmessig endring, tap og ødeleggelse. Samtidig må dokumentet kunne gjenfinnes. Etter omstendighetene vil det også kunne stilles krav om sikkerhetskopiering og passord. Dokumentene må i tillegg være lesbare og må være eller gjøres tilgjengelig fra Norge ved innsynsforespørsel. 


\section{$9 \quad$ Kildeliste}

\subsection{Lover}

1985

Lov 21. juni 1985 nr. 83 om ansvarlige selskaper og kommandittselskaper (selskapsloven).

1988

Lov 13. mai 1988 nr. 26 om inkassovirksomhet og annen inndriving av forfalte pengekrav (inkassoloven).

1997

Lov 13. juni 1997 nr. 44 om aksjeselskaper (aksjeloven).

1997

2003

Lov 4. august 2003 nr. 83 om elektronisk kommunikasjon (ekomloven).

Lov 14. juni 2013 nr. 40 om endringer i aksjelovgivningen mv. (forenklinger).

Lov 16. juni 2017 nr. 71 om endringer i aksjelovgivningen mv. (modernisering og forenkling).

2018

Lov 15. juni 2018 nr. 38 om behandling av personopplysninger (personopplysningsloven).

\section{$9.2 \quad$ Forarbeider}

Knudsen-utredningen

Forenkling og modernisering av aksjeloven. En utredning av advokat Gudmund Knudsen. Skrevet etter oppdrag fra Justis- og politidepartementet. Oslo, 07.01.2011.

NOU 1996: 3

Ny aksjelovgivning.

NOU 2016: 22

Aksjelovgivning for $\phi k t$ verdiskapning. 
Ot.prp. nr. 77 (2000-2001) Om lov om endringer i likestillingsloven mv. (plikt til å arbeide for likestilling, skjerping av forbudet mot forskjellsbehandling på grunn av kjønn, forbud mot seksuell trakassering $m v$.).

Ot.prp. nr. 108 (2000-2001) Om lov om endringer $i$ diverse lover for å fjerne hindringer for elektronisk kommunikasjon.

Prop. 111 L (2012-2013) Endringer i aksjelovgivningen mv. (forenklinger).

Prop. 6 L (2016-2017) Endringer i tinglysingsloven, inkassoloven og tvangsfullbyrdelsesloven $\mathrm{mv}$. (teknologinфytralitet).

Prop. 112 L (2016-2017) Endringer i aksjelovgivningen mv. (modernisering og forenkling).

\subsection{Rettspraksis}

Rt. 2007 s. 817

Rt. 2013 s. 241

Stangeskovene.

\section{$9.4 \quad E U$}

Personvernforordningen

(GDPR)

Aksjonærrettighetsdirektivet

Digitaliseringsrapporten
Regulation (EU) 2016/679 of the European Parliament and of the Council of 27 April 2016 on the protection of natural persons with regard to the processing of personal data and on the free movement of such data, and repealing Directive 95/46/EC, 27.04.2016.

Directive 2007/36/EC of the European Parliament and of the Council of 11 July 2007 on the exercise of certain rights of shareholders in listed companies, 11.07.2007.

Report on digitalisation in company law, 24.03.2016. [https://ec.europa.eu/info/sites/info/files/icleg-report-ondigitalisation-24-march-2016_en.pdf] hentet 18.10.2019. 


\section{$9.5 \quad$ Litteratur}

Aarbakke m.fl. (2017)

Andenæs m.fl. (2016)

Bråthen (2014)

Bråthen (2017)

Bråthen og Minde (2017)

Equinor.com
Aarbakke, Magnus, Asle Aarbakke, Gudmund Knudsen, Tone Ofstad og Jan Skåre. Aksjeloven og allmennaksjeloven. Lovkommentar. 4. utg. Oslo: Universitetsforlaget, 2017.

Andenæs, Mads Henry, Aksjeselskaper og allmennaksjeselskaper. 3. utg. ved Ole Andenæs, Stig Berge og Margrethe Buskerud Christoffersen. Oslo: M.H. Andenæs, 2016.

Bråthen, Tore. «Kommentar til aksjeloven» i Norsk lovkommentar, Gyldendal rettsdata 2014 hentet 18.10.2019.

Bråthen, Tore. Den norske aksjelovreformen - 1. etappe 2017. Nordisk tidsskrift for Selskapbsret (2017), s. 70-86.

Bråthen, Tore og Stine Winger Minde. Nye norske regler om utarbeidelse og oppbevaring av selskapsdokumentasjon og kommunikasjon mellom aksjonarer og aksjeselskap. Nordisk tidsskrift for Selskabsret (2017), s. 104-115.

Equinor ASA. Generalforsamling 2019. https://www.equinor.com/no/what-we-do/calendar/annualgeneral-meeting-2019.html hentet 03.08.2019. 